\title{
Investigating the Business Cycles of the Iranian Economy by Considering the Effect of Financial Accelerator in the Form of a DSGE Model
}

\author{
Abolfazl Garmabi ${ }^{1}$ \\ Seyed Ahmadreza Jalali-Naini ${ }^{2}$ \\ | agarmabi@mporg.ir \\ Hossein Tavakolian ${ }^{3}$ \\ | a.jalali@imps.ac.ir \\ | hossein.tavakolian@atu.ac.ir
}

Received: 28/04/2021 | Accepted: 01/08/2021

\begin{abstract}
The present study attempts to analyze the effect of the financial accelerator component on the business cycles of the Iranian economy by considering the financial friction in the process of obtaining bank loans. In addition, the inclusion of banks 'capital adequacy ratio in the model enters the role of banks' balance sheets in the occurrence of financial friction in the Iranian economy. Weak credit rating of bank customers in Iran makes it possible to use a document-based approach to properly understand the financial friction in the credit system, instead of using the inspection algorithm of lending banks and covering their costs through different interest rates. For this purpose, a dynamic stochastic general equilibrium model (DSGE) is designed in accordance with the structural features of the Iranian economy, and is estimated using the Bayesian approach and seasonal data in the period 2020-2009. The results indicate that taking the financial sector into account leads to a more accurate understanding of the fluctuations of business cycles in the Iranian economy. This is determined by comparing the instantaneous reaction functions of the main variables of the model in two scenarios with different degrees of financial friction. The results of the study also show that the changes due to the financial accelerator component in the impact of monetary shocks and productivity are more noticeable than other shocks.
\end{abstract}

Keywords: Business Cycles, Financial Accelerator, Financial Friction, DSGE Model, Bayesian Estimation.

JEL Classification: E31, E32, E44, C11.

\footnotetext{
1. Ph.D. Student of Economics, Institute for Management and Planning Studies, Tehran, Iran (Corresponding Author).

2. Professor, Institute for Management and Planning Studies, Tehran, Iran

3. Associate Professor, Faculty of Economics, Allameh Tabataba'i University, Tehran, Iran
} 


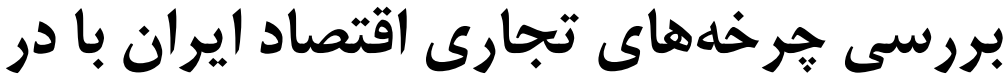

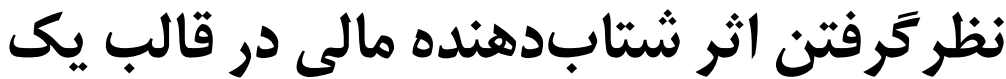

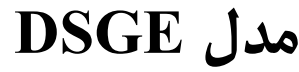

a.garmabi@mporg.ir

ابوالفضل تر مابى لمانى

تانشجوى دكترى اقتصاد موسسه عالى آموزش و يرؤهش مديريت و برنامهريزى، إئى

تهران، ايران (نويسنده مسئول).

a.jalali@imps.ac.ir

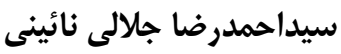

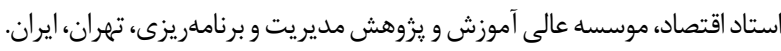
hossein.tavakolian@atu.ac.ir |

حسين توكليان

دانشيار دانشكده اقتصاد دانشكاه علامه طباطبايى، تهران، ايران.

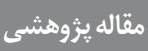

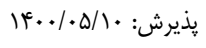

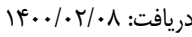

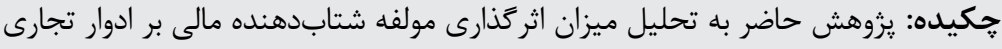

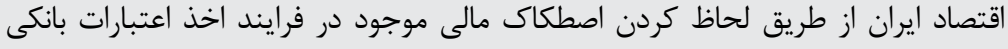

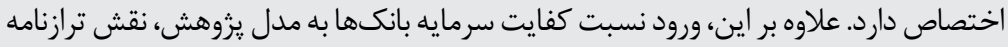

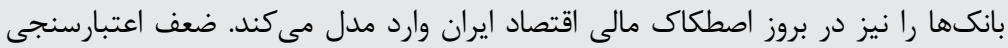

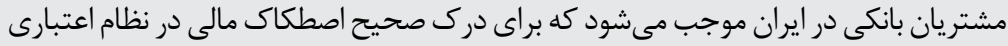

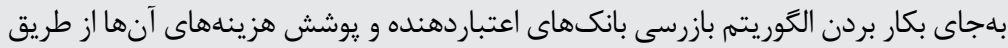

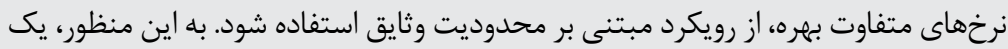

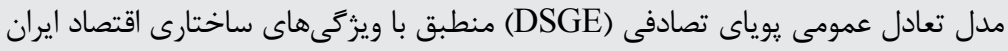

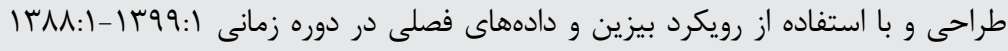

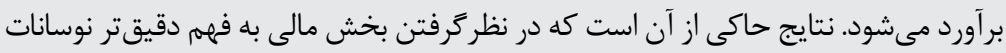

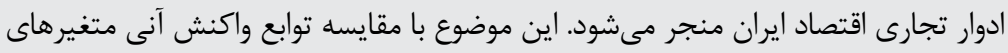

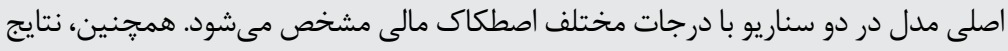

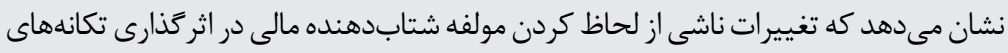

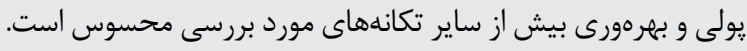

كليدوازٔها: ادوار تجارى، شتابدهنده مالى، اصطكاك مالى، مدل DSGE DSGE، تخمين بيزين. طبقدبندى E32, E31 E44, C11 :JEL. 
در جند دهه اخير بخش مالى نقش مهمى در جهت گيرى فعاليت اقتصادى كشورها داشته است. توسعه بخش مالى شتاب جرخههاى تجارى مسلط را تقويت نموده و در بسيارى موارد به نوسان شديد در شرايط اقتصادى منجر شده است (Bartmann, 2017). در اين ميان بروز بحرانهاى مالى در دهههاى اخير به تمركز يزوهشكران اقتصادى بر اثرات بىثباتى مالى بر پايدارى بخش حقيقى اقتصاد

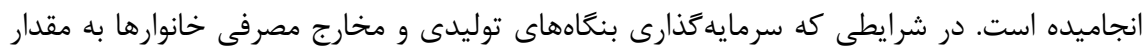

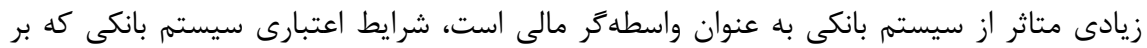

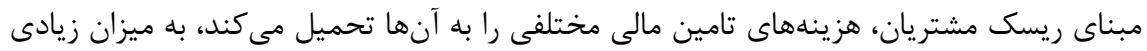

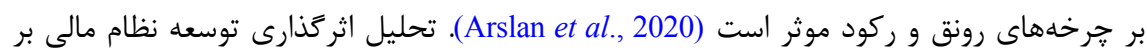
رشد بخش حقيقى اقتصاد و קرخههاى تجارى مستلزم در نظركرفتن يديده لاصطكاى بازار مالى"

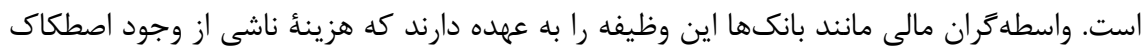

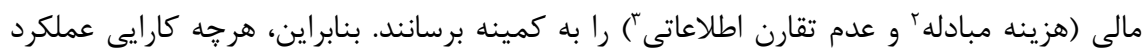

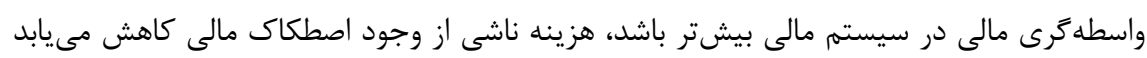
(Arslan et al., 2020)

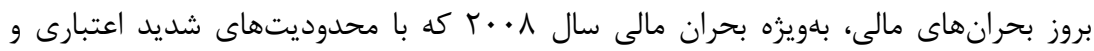

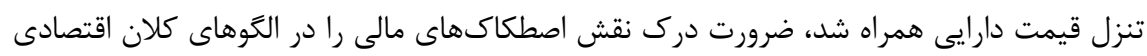

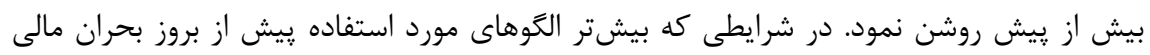

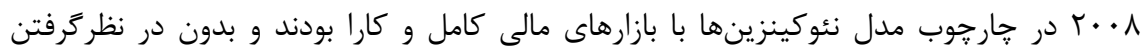

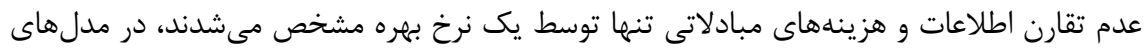

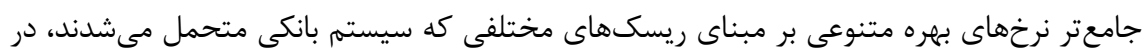

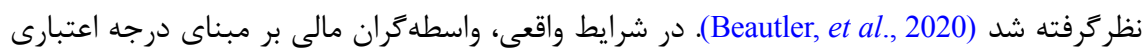
قرض در نظر مى گيرند و آن را به عنوان نرخ بهره وجوه از مشتريان دريافت مىنمايند. مولفه اطلاعات

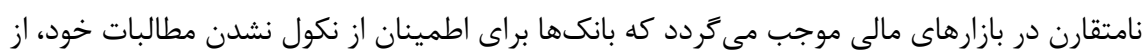

1. Financial Market Friction

2. Transaction Cost

3. Information Asymmetry 
قرض كيرندكان بخواهند توانايى خود را براى بازيس دادن بدهى اغلب به شكل دارايىهاى وثيقهاى

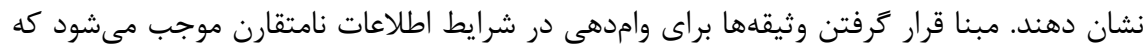

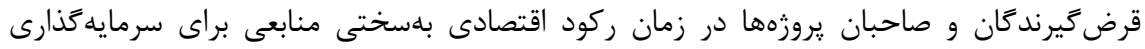

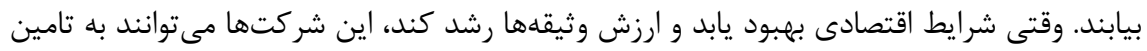

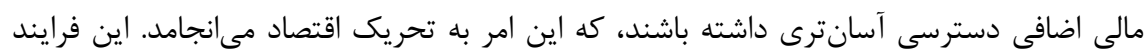

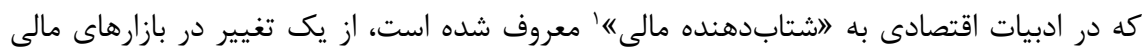

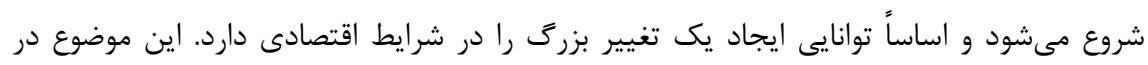

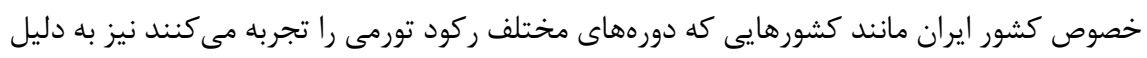

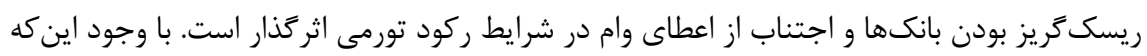

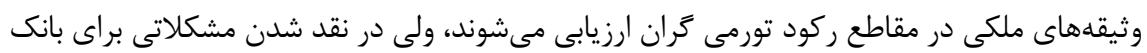

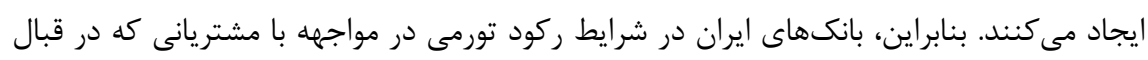

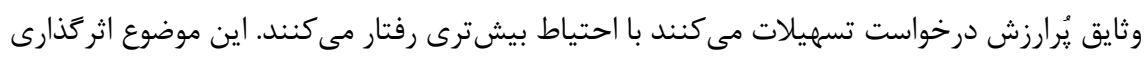

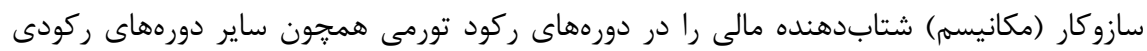
مشابه الكوهاى استاندارد تاييد مى كند.

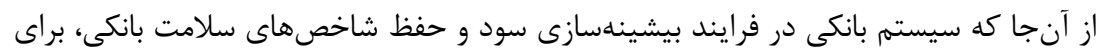

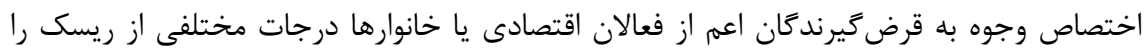

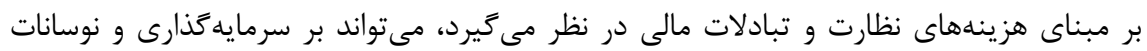

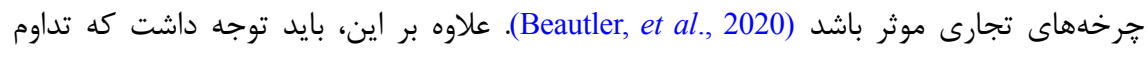

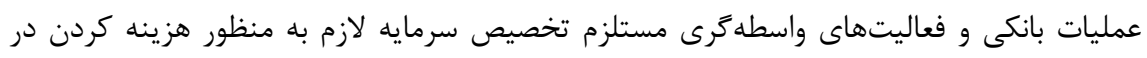

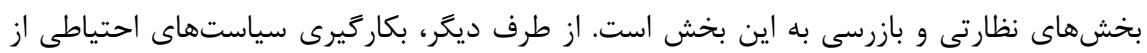

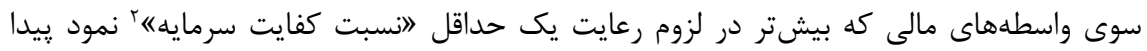

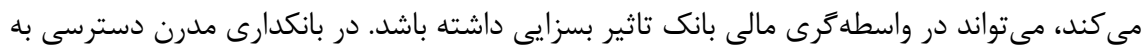

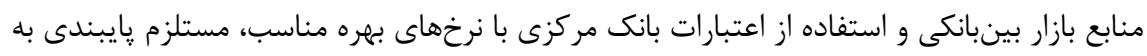

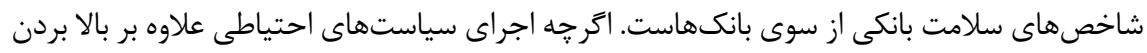

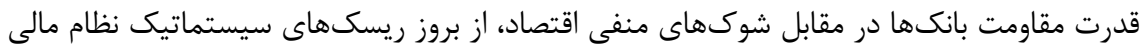


جلو گيرى مى كند، ولى خود اين مسئله مى تواند بر فعاليتهاى واسطه گرى بانكها و به تبع آن فعاليت

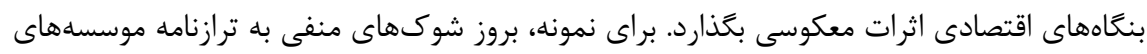
مالى و اعتبارى كه ممكن است از تغيير سياستهاى يولى و مقرراتى يا از دست رفتن سرمايه بانكها ناشى شود، مى تواند باعث كاهش اعتباردهى موسسههاى مالى به بنحاههاى اقتصادى گردد و در نتيجه اين شوكها را به اقتصاد واقعى منتقل كند. در ادبيات اقتصادى سه كانال اصلى براى انتقال شوكهاى ناشى از بخش يولى -مالى به اقتصاد واقعى و تشديد و سرايت شوكهاى ناشى از بخش واقعى با واسطة بخش يولى -مالى به كل اقتصاد

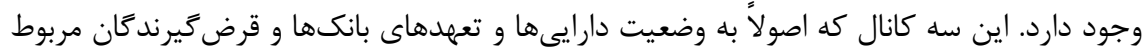

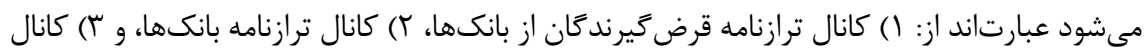

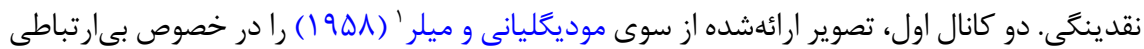
هزينه تامين مالى از ساختار سرمايه (تركيب بدهى و سرمايه) و روشهاى تهائ تامين مالى شركتها

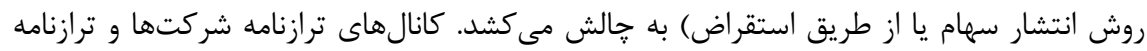

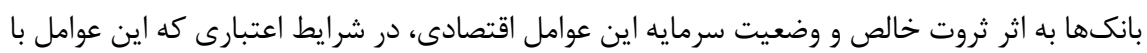
آنها مواجه هستند، اشاره دارند. هر دو كانال ترازنامهاى به عنوان نتيجهُ اصطكاك بازار اعتبار ــ مانند

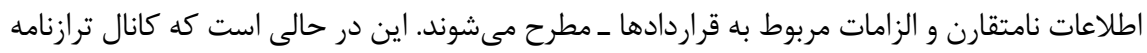

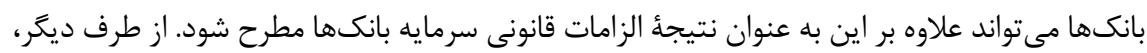
كانال سوم به موقعيت نقدينكى بانكها تاكيد دارد و انعطافنايذيرى و درجه نقدشوندكى متغيرهاى ترازنامه شر كتها را بررسى مى كند. تمركز اصلى يزوهش حاضر بر سنجش ميزان اثركذارى اصطكاك مالى بر ادوار تجارى اقتصاد

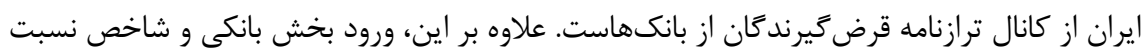

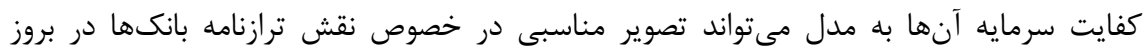

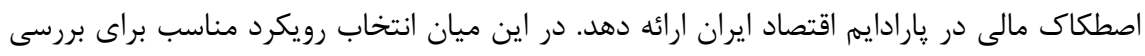
اثر شتابدهنده مالى بر اقتصاد ايران مستلزم شناخت ويزگى هاى بازار اعتبارى كشور ايران است. از يك طرف در نظام بانكى ايران مولفه اعتبارسنجى مشتريان بانكى بهطور ضعيف عمل ميى كند و از

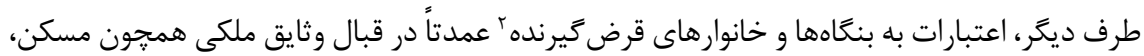


ساختمان، و زمين اعطا مىشود. اين موضوع باعث مىشود كه استفاده از الكوريته بازرسى بانكهاى

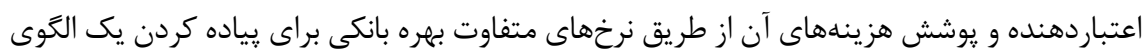

بنابراين، در اينجا براى اندازهگيرى اثر شتابدهنده مالى بهجاى روش برنانكه و همكاران'

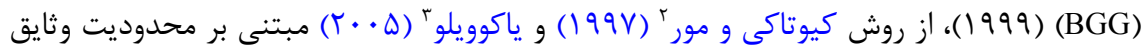

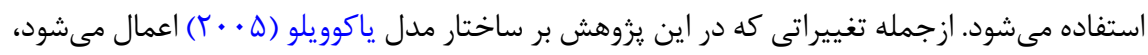
ورود بخش بانكى به منظور درى روشنتر سازوكار اعطاى اعتبارات و لحاظ كردن سيردهها و نرخ بهره

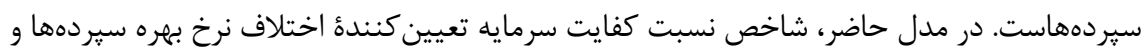

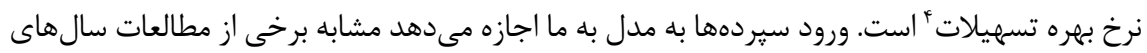

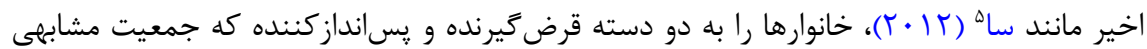

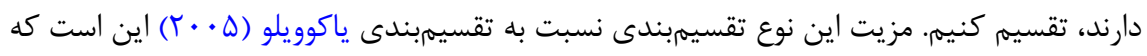
با لحاظ كردن نرخهاى ترجيح زمانى متفاوت به اين دو نوع خانوار، مىتوان فرض كرد كه در وضعيت

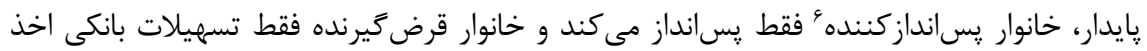
مى كند. بنابراين، هدف اصلى يزوهش حاضر بررسى ميزان اثر كذارى مولفه شتابدهنده مالى بر ادوار تجارى اقتصاد ايران از طريق لحاظ اصطكاى مالى موجود در فرايند اخذ اعتبارات و ارزيابى كانال

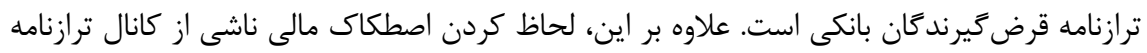
بانكها و در نظرگرفتن شاخص نسبت كفايت سرمايه بانكها مىتواند درى كاملترى از اثركذارى سازوكار شتابدهنده مالى بر اقتصاد ايران ارائه دهد. همان طور كه كفته شد، عدم تطابق مدل هاى مبتنى بر اعتبارسنجى بانكها و اعمال نرخهاى بهره

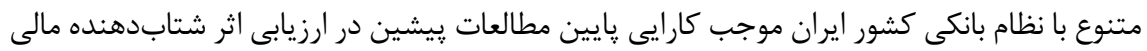
بر جرخههاى تجارى اقتصاد ايران مىشود. سهم يزوهش حاضر برطرف كردن كاستى مزبور و ارائه مدلى براى توصيف اثرات اصطكاك مالى بر جرخههاى تجارى بر پايه وثيقههاى بانكى است. در اين

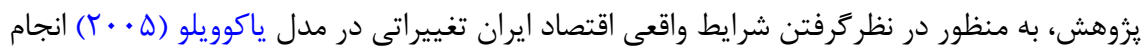

1. Bernanke et al.

2. Kiyotaki \& Moore

3. Iacoviello

4. Bank Spreads

rv

5. Suh

6. Saving Household 
مىشود. استفاده از نوع تعديلشده قاعده تيلور براى سياست يولى مبتنى بر رشد يول بهجاى نرخ

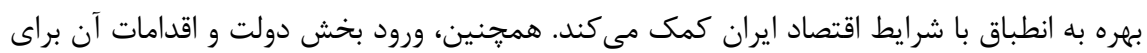
تامين مالى و البته ورود نفت به عنوان يك متغير مهمم و اثركذار بر اقتصاد ايران از تغييرات اساسى لهى

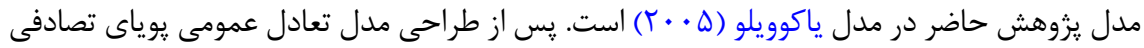

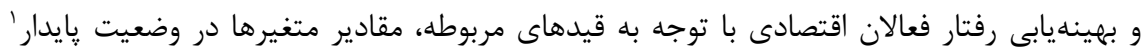
بررسى مىشود و سيس انحراف معيار آنها از اين مسير در صورت وارد شدن شوكهاى مختلف به به به مدل ارزيابى مىشود. در اين يروهش، بر يايه ادبيات موضوع و شواهد تجربى اقتصاد ايران اثبات اين

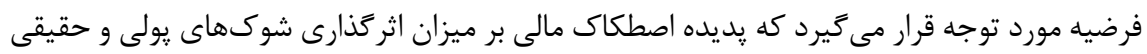

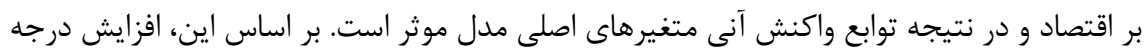

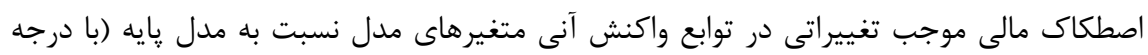

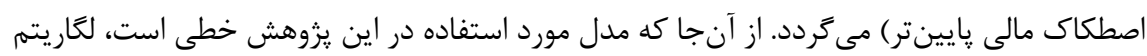
خطى سازى معادلات مورد توجه قرار مى گيرد.

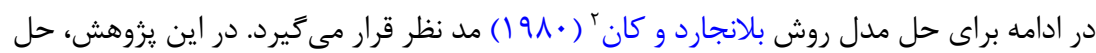

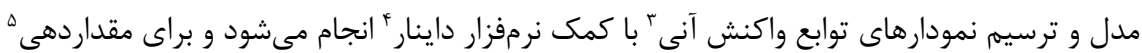

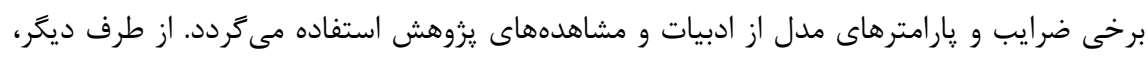

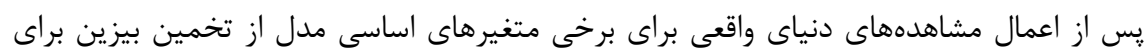

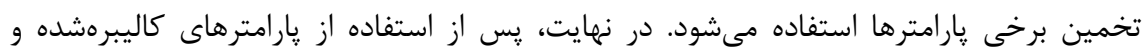

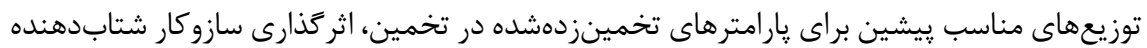

$$
\text { مالى مورد بررسى قرار مى گيرد. }
$$

\section{مبانى نظرى : مثروهش}

نظريه شتابدهنده مالى در اقتصاد كلان بر اين ايده استوار است كه شوكهاى منفى به اقتصاد

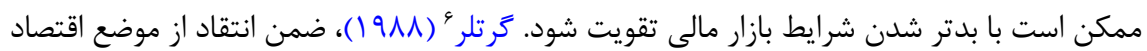

1. Steady State

2. Blanchard \& kahn

3. Impulse Response Functions

4. Dynare

5. Calibration

6. Gertler 
كلان در خصوص بخش مالى، اين فرض نظريه اقتصاد كلان كه در اغلب موارد نوسانات سيستم مالى

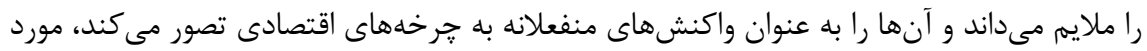
انتقاد قرار مى دهد. وقوع بحرانهاى مالى نشان مى دهد كه روند ضعيفتر شدن بازار اعتبار و افزايش

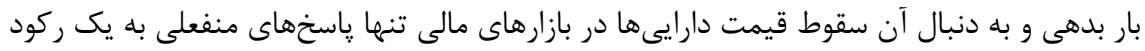
اقتصادى نيست، بلكه خود اين نوسانات مالى مىتوانند عامل اصلى در منقبض شدن فعاليتهاى بـى بـ اقتصاد واقعى باشند. نقش بالقوه بازار مالى در ادبيات اقتصادى یس از دو دهه مورد بررسى قرار كرفت

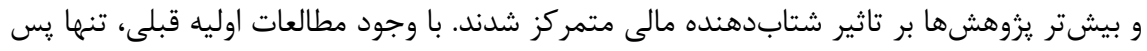

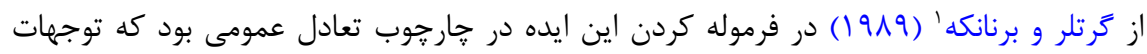

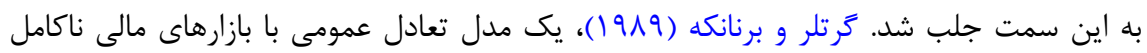

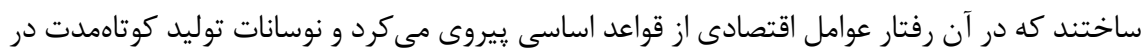

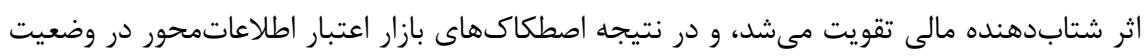
اطلاعات نامتقارن به كل اقتصاد سرايت مى كرد.

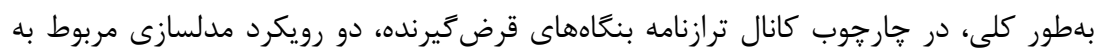
كَرتلر و برنانكه (9199 (19) و كيوتاكى و مور (991) وجود دارد كه عدم تقارن اطلاعات در بازار اعتبار

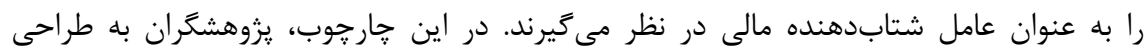
سناريوهاى ممكنى كه قرضدهند

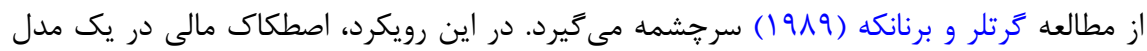

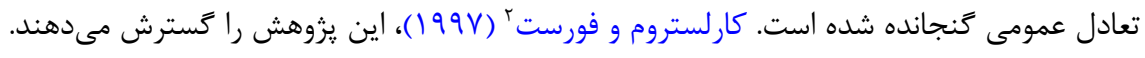

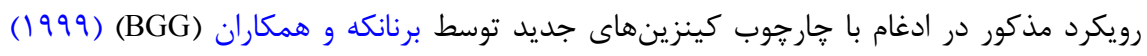
به مدل شتابدهنده مالى تبديل شد. در اين مدل، اصطكاك از طريق هزينه نظارت بر متقاضى وام

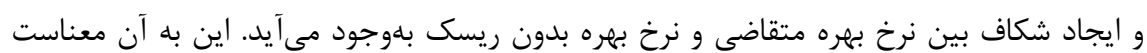

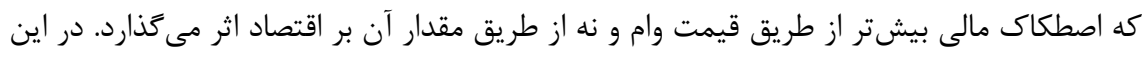
مدل فرض مىشود كه بين هزينه تامين مالى خارجى و داخلى تفاوت وجود دارد. ياداش تامين مالى لى

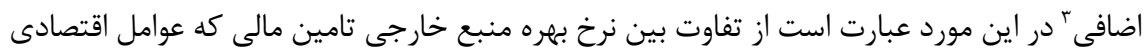

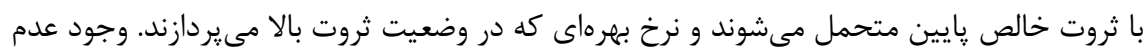

1. Gertler \& Bernanke 
تقارن اطلاعات باعث مىشود وامدهندًان با هزينه حسابرسى و نظارت مواجه شوند. بنابراين، بين وامدهند خارجى براى بنگًاه منجر مى در مدل برنانكه و همكاران (999) به تبعيت از گَرتلر و برنانكه (9199)، براى مدل كردن

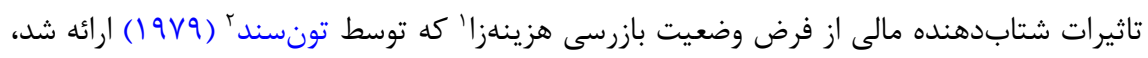
استفاده شده است. اين فرضيه بيان مى كند مشكلاتى كه به وسيله اطلاعات نامتقارن بين قرض دهنيده

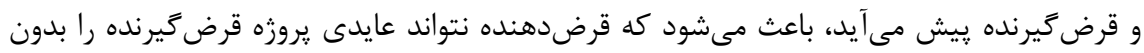

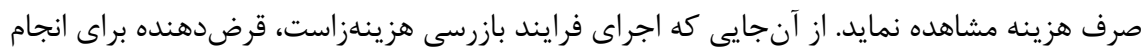

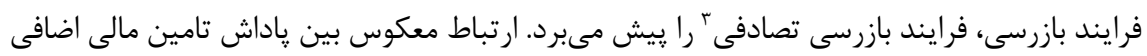

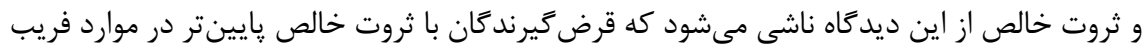
بانكها، ثروت كمترى براى از دست دادن دارند. از آنجايى كه بانكها فرايند بازرسى تصادفى دئ راند

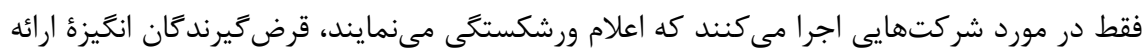

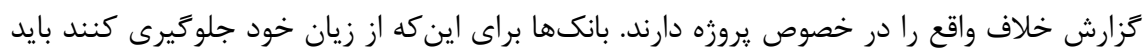

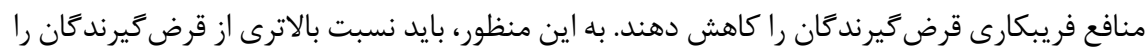

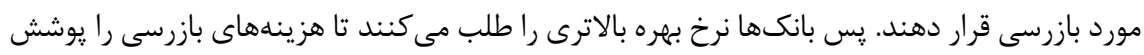
دهند. در نتيجه، زمانى كه شوك اقتصادى ثروت قرض گميرند

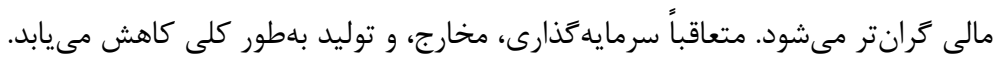

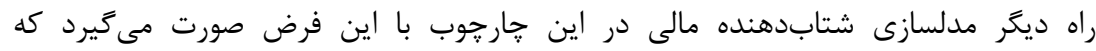

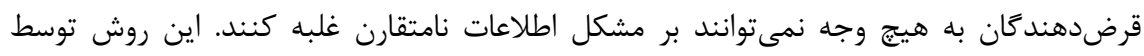

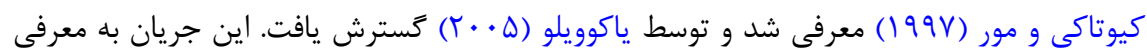
اصطكاى مالى از طريق محدوديت وثيقهاى مىيردازد. افراد از لحاظ نرخ ترجيح زمانى ناهمگن

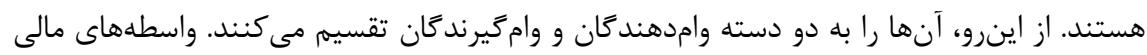

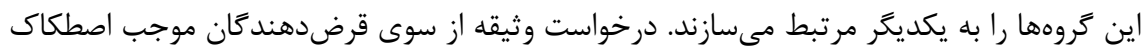

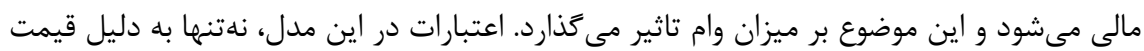

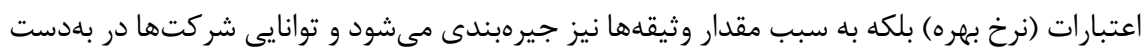

1. Costly State Verification Hypothesis

2. Townsend

3. Random Verification Procedure 


$$
\text { آوردن وامها مستقيماً به ارزش وثيقههايى كه آنها مى گذارند بستخى دارد. }
$$

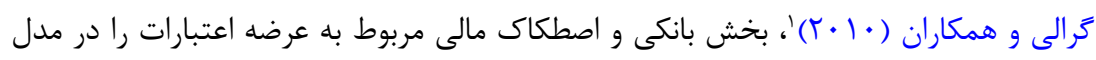

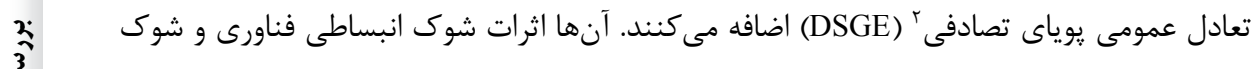

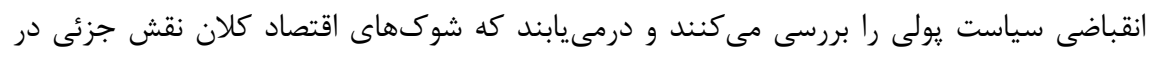

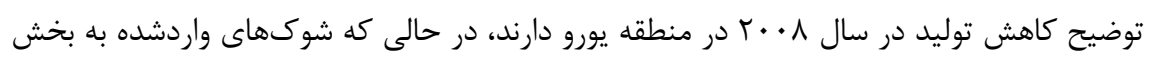

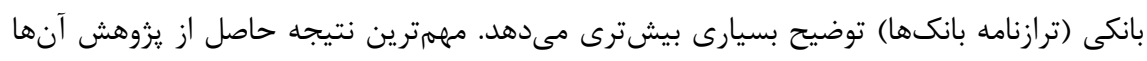

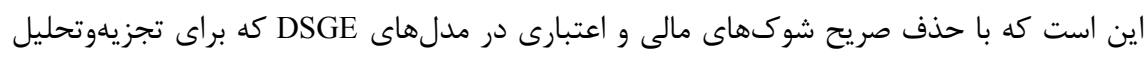
نوسانات جرخههاى تجارى طراحى مىشوند، قابليت شبيهسازى شرايط واقعى اقتصاد بسيار كاهش

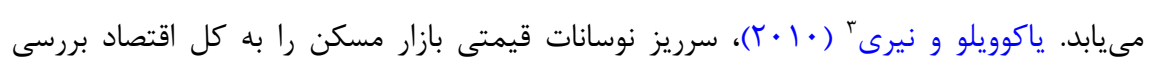

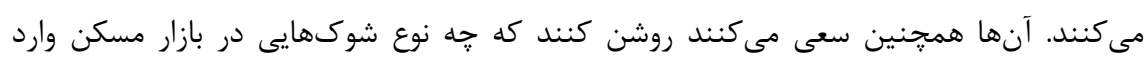

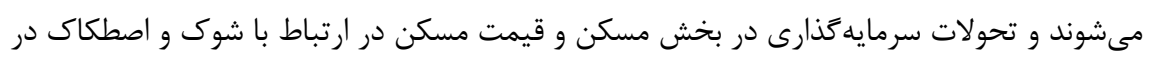

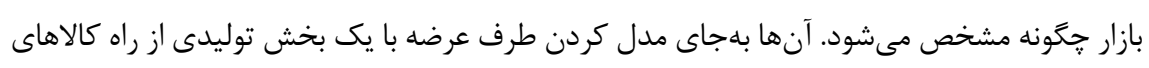

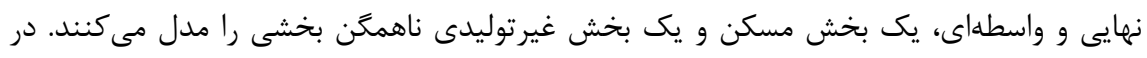
اين رويكرد مدلسازى، غير از تاثير سنتى بر محدوديتهاى استقراض ناشى از افزايش قيمت خانى خانه، تاثيرات ديخرى ناشى از سود نسبى توليد خانههاى جديد به مدل اضافه ميى شود. اين رويكرد سازوكار

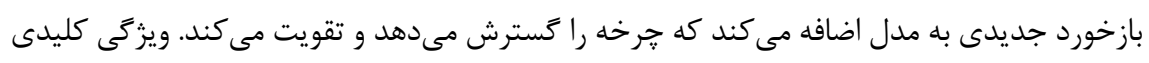

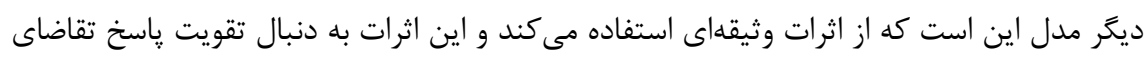

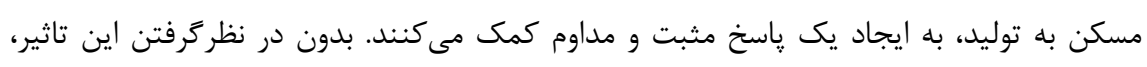

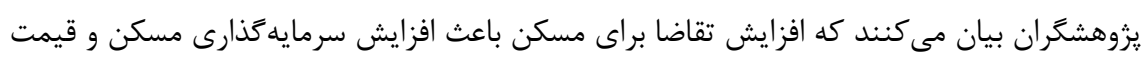

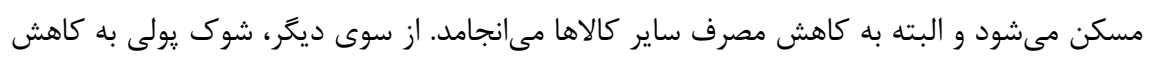

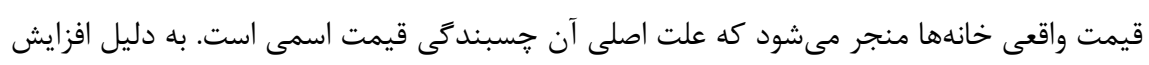

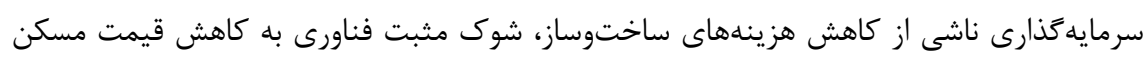

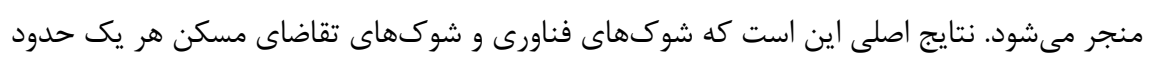
يك جهارم نوسان دورهاى را در سرمايهَذارى مسكن و قيمت مسكن توضيح مى دهند. از سوى ديكر، اين موضوع مورد توجه قرار مى گيرد كه سرريز به ساير بخشهاى اقتصاد بسيار مههم است، اما اين

\section{Gerali et al.}

2. Dynamic Stochastic General Equilibrium 3. Iacoviello \& Neri 
تاثير بيش از سرمايهَذارى در تجارت بر مصرف متمركز است.

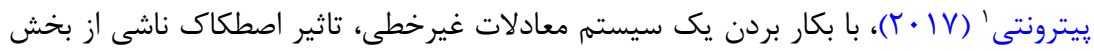
مالى را بر اقتصاد ايتاليا بررسى مى كند. ورود بخش بانكى با محدوديتهاى مقطعى ضرورى براى

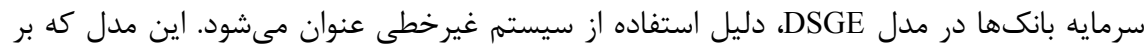

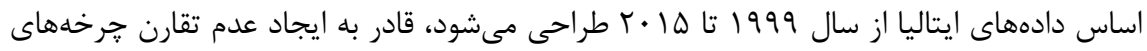
تجارى همانند دادههاى واقعى است كه نمىتواند توسط مدلهاى خطى تكرار شود. اين مطالعه نشان مى دهد كه فعالسازى اين ابزارهاى سياستى مى تواند نوسانات سيكل هاى تجارى را كاهش دهاى دهد.

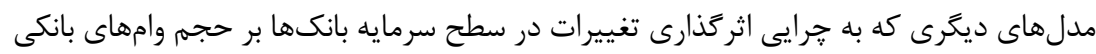

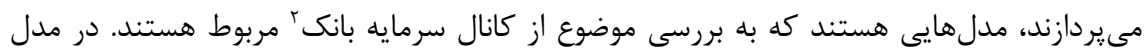

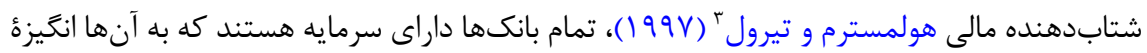
نظارت بر قرض گيرند

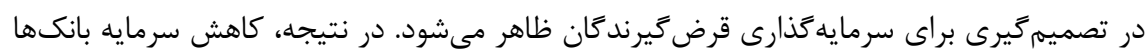

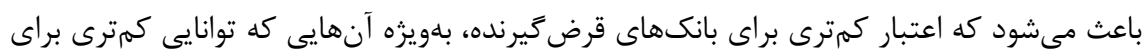
وثيقهذذارى دارند، فراهم گردد. وقوع هر شوك مالى يا واقعى كه تاثير كاهنده بر سرمايه بانكها

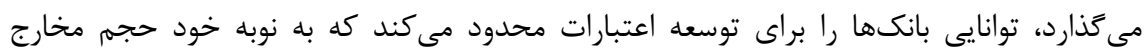

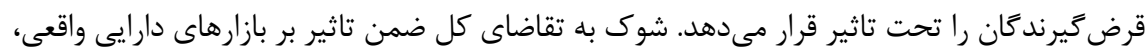

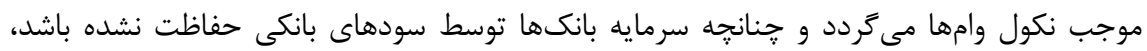

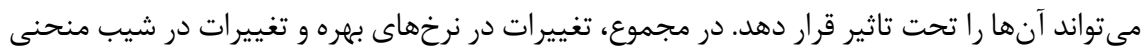

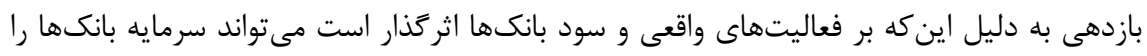

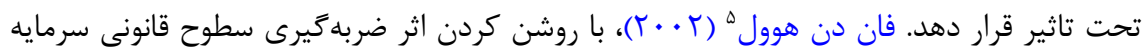

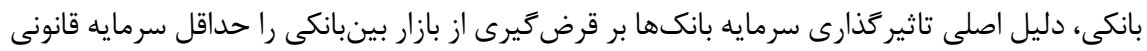

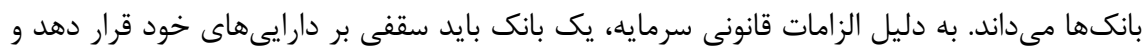

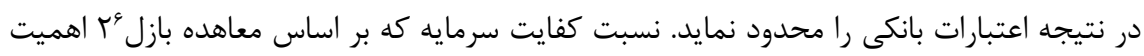

\section{Pietrunti}

2. Capital Channel

3. Holmstrom \& Tirole

4. Moral Hazard

5. Van den Heuvel

6. Basel II 
دوجندان يافته است و بلطور بالقوه مىتواند تاثيرات سرمايه بانكها را بر قرضدهى شديدتر كند، به

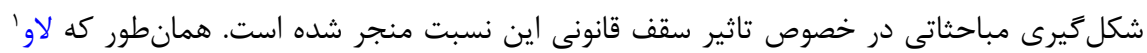

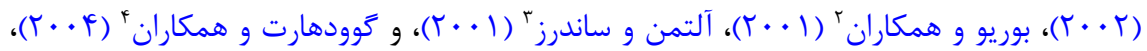

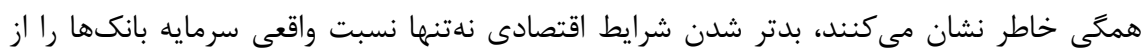

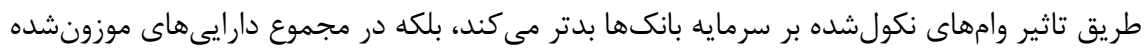

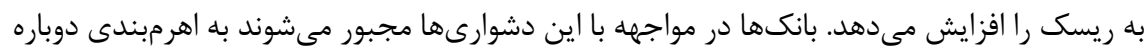

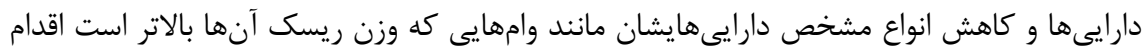

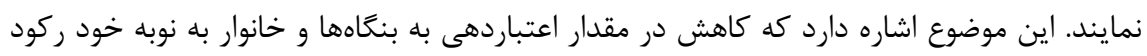

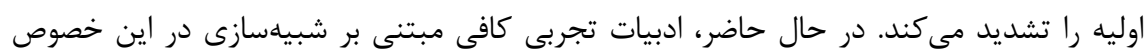

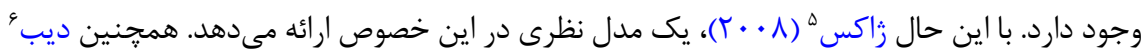

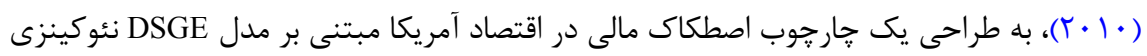

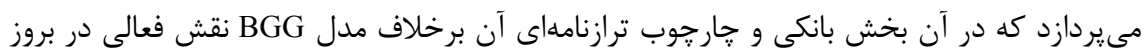

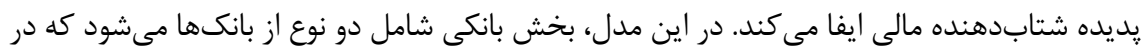

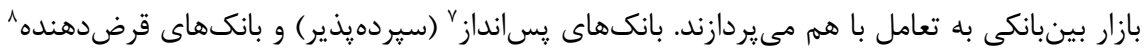

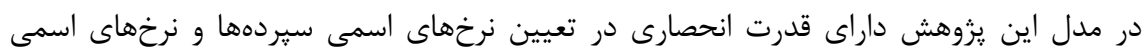

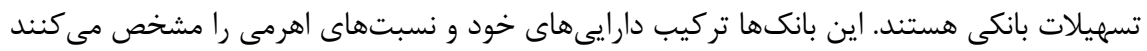

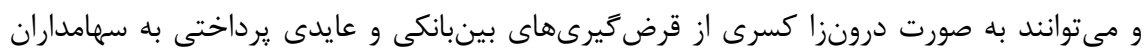

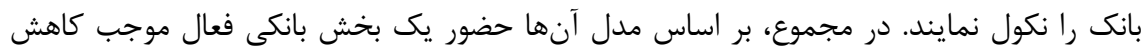

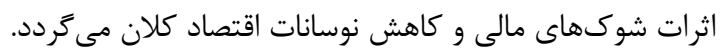

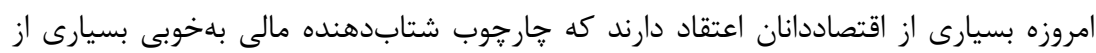

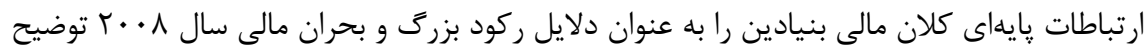

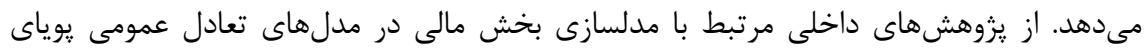

1. Lowe

2. Borio et al.

3. Altman \& Saunders

4. Goodhart et al.

5. Jacques

6. Dib 


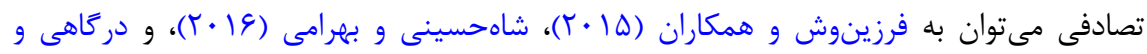

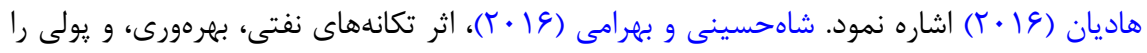
بر متغيرهاى كلان حقيقى و بخش مالى اقتصاد ايران در يك مدل تعادل عمومى يوياى تصادفى با

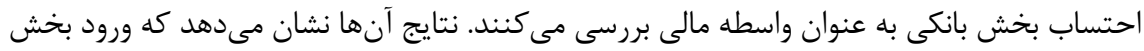

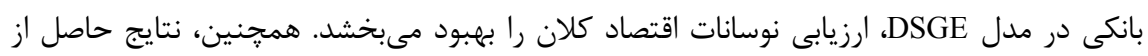
شبيهسازى نشان مىدهد كه حركت متغيرهاى بخش بانكى با ادوار تجارى ايران همجهت است كه امكان توضيح نقش بانكها را به عنوان شتابدهنده مالى و تبيين كانال انتقال يولى در اقتصاد ايران

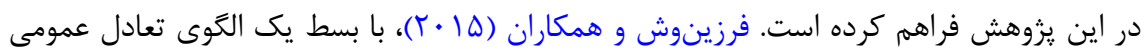

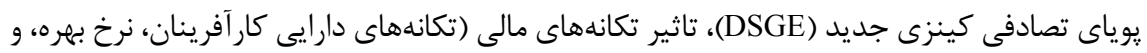

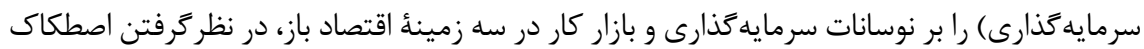

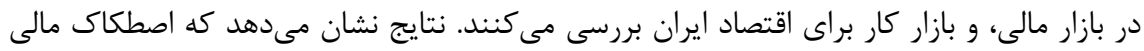

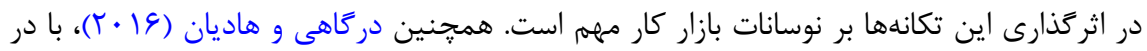

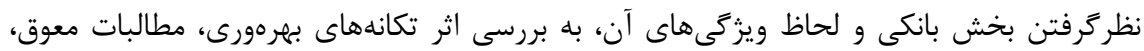

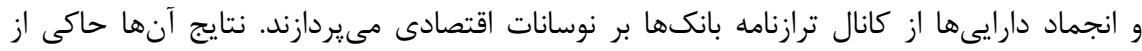
اثريذيرى ادوار تجارى اقتصاد ايران از ادوار مالى است.

\section{معرفى مدل}

همان گونه كه گفته شد، الخوى اين مطالعه بر يايه سازوكار شتابدهنده مالى معرفىشده توسط

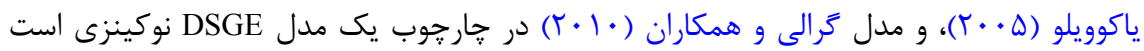

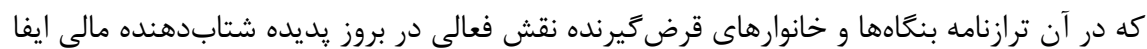

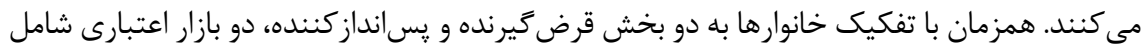

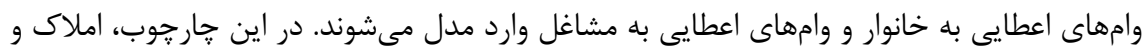
كالاى مسكن علاوه بر حضور در تابع مطلوبيت خانوار قرض بازى مى كند. از طرف ديخر، املاك وثيقه كذارىشده توسط بنعاهها موجب اخذ اعتبار بانكى ميىشود. 


\section{خانوارها}

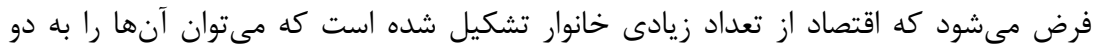

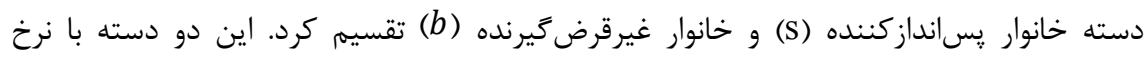

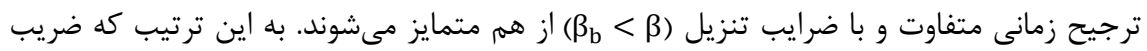

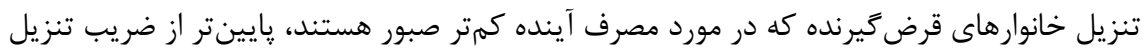

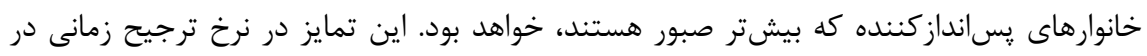

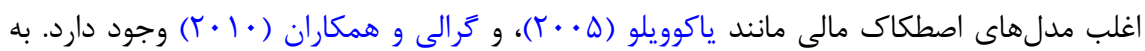

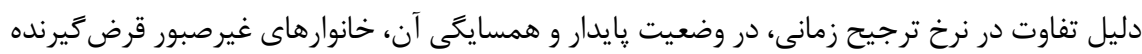

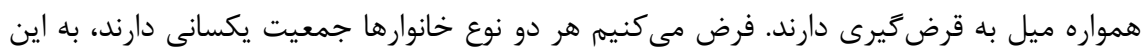

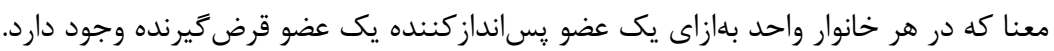

\section{خانوارهاى يسانداز كننده}

خانوار پساندازكننده كه آن را با انديس (S) نشان مىدهيم، با ضرهيب تنزيل

$E_{0}\left\{\sum_{t=0}^{\infty} \beta^{t}\left[\ln \left(C_{t}^{S}\right)+\vartheta_{t}^{h} \ln \left(H_{t}^{S}\right)-\frac{L_{t}^{S 1+\eta}}{1+\eta}+\chi \ln \left(\frac{M_{t}^{S}}{P_{t}}\right)\right]\right\}$

در اينجا CL خانوار يساندازكننده است.

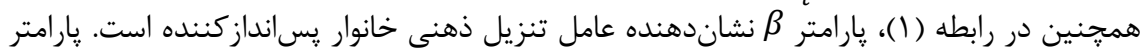

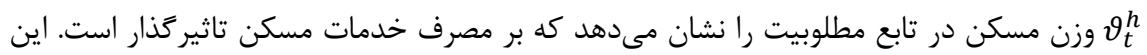

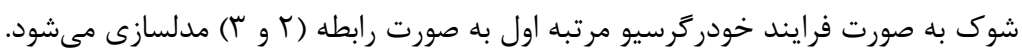
$\vartheta_{t}^{h}=\rho_{A} \vartheta_{t-1}^{h}+\varepsilon_{\vartheta . t}$ $\varepsilon_{\vartheta . t} \sim$ i.i.d $N\left(0 . \sigma_{\vartheta}^{2}\right)$

خانوار پِاندازكننده تابع مطلوبيت خود را با توجه به قيد بودجه زير بيشينه مى كند. $C_{t}^{S}+\frac{M_{t}^{S}}{P_{t}}+P_{t}^{h} H_{t}^{S}+\frac{D_{t}^{S}}{P_{t}}+T_{t}^{S} \leq \frac{M_{t-1}^{S}}{P_{t}}+R_{t}^{d} \frac{D_{t-1}^{S}}{P_{t}}+\left(1-\delta_{H}\right) P_{t-1}^{h} H_{t-1}^{S}+\mathrm{w}_{t}^{S} L_{t}^{S}$ در اينجا $w_{t}^{S}$ 


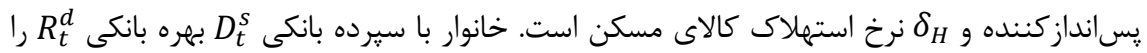

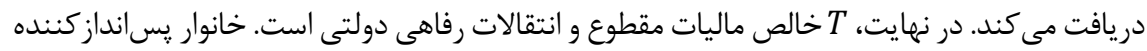
مقادير

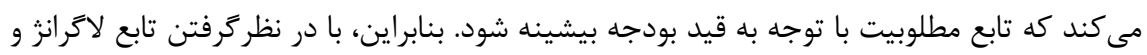

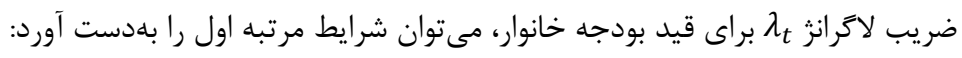

$\mathcal{L}: \quad E_{0}\left\{\sum_{t=0}^{\infty} \beta^{t}\left[\ln \left(C_{t}^{s}\right)+\vartheta_{t}^{h} \ln \left(H_{t}^{s}\right)-\frac{L_{t}^{s 1+\eta}}{1+\eta}+\chi \ln \left(\frac{M_{t}^{S}}{P_{t}}\right)\right.\right.$

$$
\left.\left.+\lambda_{t}\left(R_{t}^{d} \frac{D_{t-1}^{s}}{P_{t}}+\frac{M_{t-1}^{s}}{P_{t}}+\left(1-\delta_{H}\right) P_{t}^{h} H_{t-1}^{s}+w_{t}^{s} L_{t}^{s}-C_{t}^{s}-\frac{M_{t}^{s}}{P_{t}}-P_{t}^{h} H_{t}^{s}-\frac{D_{t}^{s}}{P_{t}}-T_{t}^{s}\right)\right]\right\}
$$

با بيشينهسازى تابع مطلوبيت بيندورهاى خانوار نسبت به قيد بودجه شرايط مرتبه اول به صورت زير بلدست مى آيد. رابطه (V) عرضه نيروى كار و رابطه (N) معادله اويلر خانوار يساندازكننده است. رابطه (9)، تصميم به تقاضاى بيندورهاى مسكن و معادله ( • () تقاضاى يول را نشان مى دهد:

$C_{t}^{s}: \frac{1}{C_{t}^{s}}=\lambda_{t}$

$L_{t}^{s}: L_{t}^{s \eta}=\frac{w_{t}}{C_{t}^{s}}$

$\frac{D_{t}}{P_{t}}: \frac{1}{C_{t}^{S}}=\beta E_{t}\left\{\frac{R_{t}^{d}}{C_{t+1}^{S}}\left(\frac{P_{t}}{P_{t+1}}\right)\right\}$

$H_{t}^{s}: \frac{P_{t}^{h}}{C_{t}^{s}}=\frac{\vartheta_{t}^{h}}{H_{t}^{s}}+\beta E_{t}\left\{\left(1-\delta_{H}\right) \frac{P_{t+1}^{h}}{C_{t+1}^{s}}\right\}$

$\frac{M_{t}^{S}}{P_{t}}: \frac{\chi}{M_{t}^{S} / P_{t}}=\frac{1}{C_{t}^{S}}-\beta E_{t}\left\{\frac{1}{C_{t+1}^{S}}\left(\frac{P_{t}}{P_{t+1}}\right)\right\}$

خانوار هاى قرض

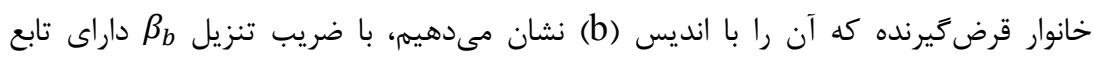
مطلوبيت بيندورهاى به صورت رابطه (1) است. (1) است $E_{0}\left\{\sum_{t=0}^{\infty} \beta_{b}^{t}\left[\ln \left(C_{t}^{b}\right)+\vartheta_{t}^{h} \ln \left(H_{t}^{b}\right)-\frac{L_{t}^{b^{1+\eta}}}{1+\eta}+\chi \ln \left(\frac{M_{t}^{b}}{P_{t}}\right)\right]\right\}$

اين تابع مشابه تابع مطلوبيت خانوار يساندازكننده تعريف مىشود و يارامتر مسكن نيز كه بر مطلوبيت مصرف خدمات مسكن تاثير گذار است، مشابه قبلى به صورت فرايند خودرگرسيو مرتبه اول مدلسازى مىشود. خانوار قرض گيرنده تابع مطلوبيت خود را نسبت به قيد بودجه و قيد محدوديت قرض گيرى بيشينه مى كند. قيد بودجه اين خانوار مشابه خانوار صبور است. 


$$
\begin{array}{r}
\text { در اين تابع متغير } B_{t}^{b} \text { مقدار تسهيلات اخذشده در قبال نرخ بهره } R_{t} \text { است } C_{t}^{b}+\frac{M_{t}^{b}}{P_{t}}+P_{t}^{h} H_{t}^{b}+R_{t} \frac{B_{t-1}^{b}}{P_{t}}+T_{t}^{b} \leq \frac{B_{t}^{b}}{P_{t}}+\frac{M_{t-1}^{b}}{P_{t}}+\left(1-\delta_{H}\right) P_{t-1}^{h} H_{t-1}^{b}+w_{t}^{b} L_{t}^{b} \text { (I r) }
\end{array}
$$

از سوى ديكر، خانوارهاى قرض

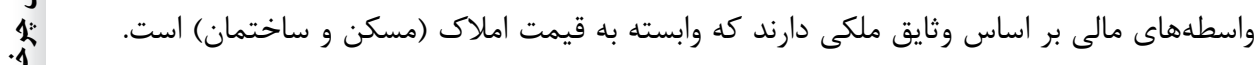

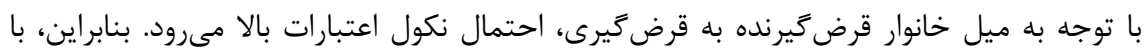
توجه به اين كه در صورت نكول اعتبارات اين نوع از خانوارها هزينههايى به واسطههاى مالى تحميل مىشود، واسطه هاى مالى مى كوشند محدوديتى در اعطاى وام بانكى براى اين خانوارها در نظر بخيرند.

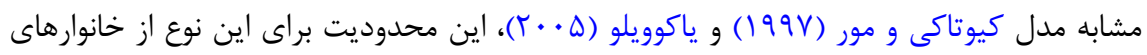

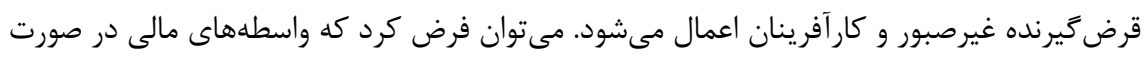
نكول قرض

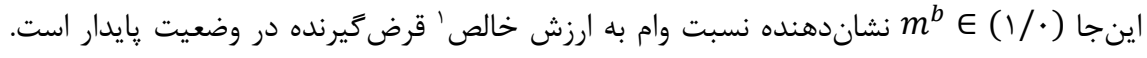
بنابراين، سقف اعتبارات اعطايى به خانوارهاى مزبور معادل

$$
\frac{B_{t}^{b}}{P_{t}} \leq m^{b} E_{t}\left(P_{t+1}^{h} H_{t}^{b} \pi_{t+1} / R_{t}\right)
$$

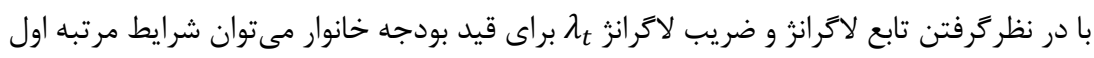

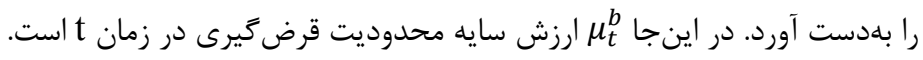

$\mathcal{L}: E_{0}\left\{\sum_{t=0}^{\infty} \beta_{b}^{t}\left[\ln \left(C_{t}^{b}\right)+\vartheta_{t}^{h} \ln \left(H_{t}^{b}\right)-\frac{L_{t}^{b^{1+\eta}}}{1+\eta}+\chi \ln \left(\frac{M_{t}^{b}}{P_{t}}\right)\right.\right.$

$$
\begin{aligned}
& \left.+\lambda_{t}\left(\frac{B_{t}^{b}}{P_{t}}+\frac{M_{t-1}^{b}}{P_{t}}+\left(1-\delta_{H}\right) P_{t}^{h} H_{t-1}^{b}+w_{t} L_{t}^{b}-C_{t}^{b}-\frac{M_{t}^{b}}{P_{t}}-P_{t}^{h} H_{t}^{b}-R_{t-1} \frac{B_{t-1}^{b}}{P_{t}}-T_{t}^{b}\right)\right] \\
& \left.+\mu_{t}^{b}\left(m^{b} P_{t+1}^{h} H_{t}^{b} \pi_{t+1}-R_{t} \frac{B_{t}^{b}}{P_{t}}\right)\right\}
\end{aligned}
$$

بنابراين، شرايط مرتبه اول براى خانوار قرض گيرنده نسبت به قيد بودجه و محدوديت قرض

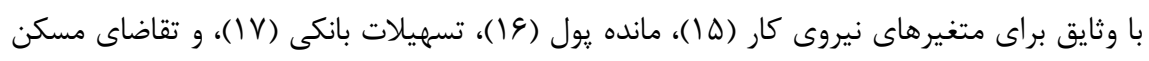

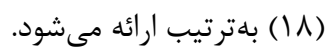

$L_{t}^{b}: L_{t}^{b^{\eta}}=\frac{w_{t}}{c_{t}^{b}}$ 


$$
\begin{aligned}
& \frac{M_{t}^{b}}{P_{t}}: \frac{\chi}{M_{t}^{b} / P_{t}}=\frac{1}{C_{t}^{b}}-\beta E_{t}\left\{\frac{1}{C_{t+1}^{b}}\left(\frac{P_{t}}{P_{t+1}}\right)\right\} \\
& \frac{B_{t}^{b}}{P_{t}}: \frac{1}{C_{t}^{b}}=\beta_{b} E_{t}\left\{\frac{R_{t}}{C_{t+1}^{b}}\left(\frac{P_{t}}{P_{t+1}}\right)\right\}+\mu_{t}^{b} R_{t} \\
& H_{t}^{b}: \frac{P_{t}^{h}}{C_{t}^{b}}=\frac{\vartheta_{t}^{h}}{H_{t}^{b}}+E_{t}\left\{\left(1-\delta_{H}\right) \beta_{b} \frac{P_{t+1}^{h}}{C_{t+1}^{S}}+\frac{\mu_{t}^{b} m^{b} P_{t+1}^{h} P_{t+1}}{P_{t}}\right\}
\end{aligned}
$$

\section{بنغًاه كار آفرين}

در اين مدل، توليدكنندكان كارآفرين توليد كالاى واسطهاى را بر عهده دارند. آنها براى اين كار از

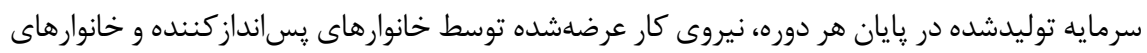

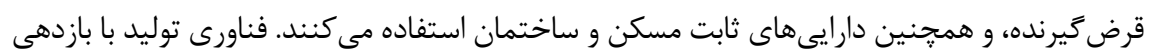

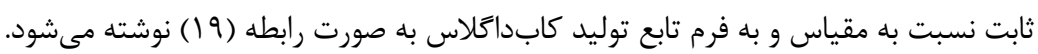
$Y_{t}=A_{t} K_{t-1}^{\sigma} H_{t-1}^{v} L_{t}^{s \alpha(1-\sigma-v)} L_{t}^{b(1-\alpha)(1-\sigma-v)}$

$$
\text { كه در آن شوك بهرهورى به صورت رابطه (· r و آT) خواهد بود: }
$$

$A_{t}=\rho_{A} A_{t-1}+\varepsilon_{A . t}$

$\varepsilon_{A . t} \sim$ i.i.d $N\left(0 . \sigma_{A}^{2}\right)$

در رابطه (• (Y)، را به خردهفروشان مىفروشد، عمدهفروشى) خواهد بود كه در آن

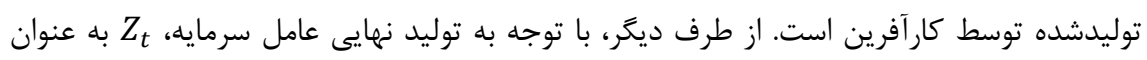
$Z_{t}=\frac{\alpha Y_{t}}{X_{t} K_{t-1}}$

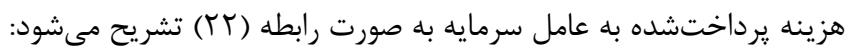

مسئله بهينهسازى بيندورهاى كار آفرين عبارت است از به بيشينه رسانيدن مطلوبيت: $E_{0} \sum_{t=0}^{\infty} \gamma^{t} \ln C_{t}$

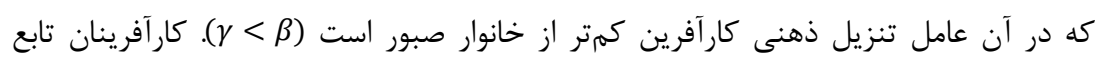

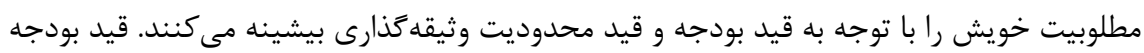
كارآفرين عبارت است ازيت 


$$
\begin{gathered}
C_{t}+P_{t}^{h} H_{t}+R_{t-1} \frac{B_{t-1}}{P_{t}}+w_{t}^{s} L_{t}^{s}+w_{t}^{b} L_{t}^{b}+I_{t}+\xi_{K t}+\xi_{H t} \\
\leq Y_{t} / X_{t}+\left(1-\delta_{H}\right) P_{t}^{h} H_{t-1}+\frac{B_{t}}{P_{t}}
\end{gathered}
$$

كه در آن t جريان سرمايه Fذارى بنگًاه با توجه به ضريب استهلاك سرمايه $\delta$ عبارت است از: $I_{t}=K_{t}-(1-\delta) K_{t-1}$ در قيد بودجه هزينههاى تعديل سرمايه و موجودى املاك بلترتيب با

$$
\begin{aligned}
& \xi_{K t}=\frac{\psi_{K}}{2 \delta}\left(\frac{I_{t}}{K_{t-1}}-\delta\right)^{2} K_{t-1} \\
& \xi_{H t}=\frac{\psi_{H}}{2 \delta}\left(\frac{H_{t}-H_{t-1}}{H_{t-1}}\right)^{2} H_{t-1}
\end{aligned}
$$

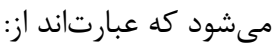

واسطههاى مالى در مواجها با تقاضاى قرض گيرى بنعاه كارآفرين، كه با استفاده از وثايق ملكى

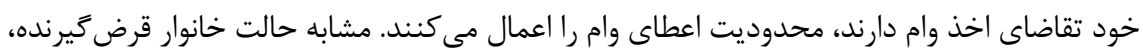
فرض مىشود كه واسطههاى مالى در صورت نكول كار آفرين نسبت (m - 1 ) را از ارزش وثايق هزينه

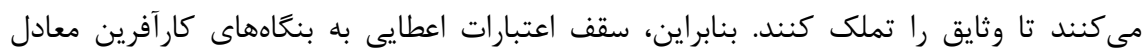
خواهد بود. يس قيد محدوديت قرض $m_{t}\left(P_{t+1}^{h} H_{t} \pi_{t+1} / R_{t}\right)$ $\frac{B_{t}}{P_{t}} \leq m E_{t}\left(P_{t+1}^{h} H_{t} \pi_{t+1} / R_{t}\right)$

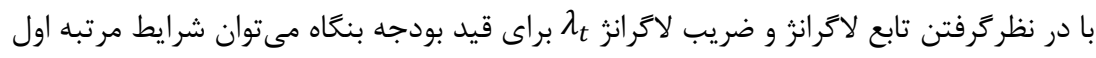

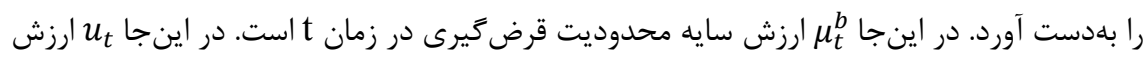
سايه محدوديت سرمايهگذارى در زمان t است.

$$
\begin{aligned}
\mathcal{L}: E_{0}\left\{\sum_{t=0}^{\infty} \gamma^{t}[\right. & l n\left(Y_{t} / X_{t}+\left(1-\delta_{H}\right) P_{t}^{h} H_{t-1}+\frac{B_{t}}{P_{t}}-P_{t}^{h} H_{t}-R_{t-1} \frac{B_{t-1}}{P_{t}}-w_{t}^{s} L_{t}^{s}-w_{t}^{b} L_{t}^{b}-I_{t}-\xi_{K t}-\xi_{H t}\right) \\
& +\lambda_{t}\left(Y_{t} / X_{t}+\left(1-\delta_{H}\right) P_{t}^{h} H_{t-1}+\frac{B_{t}}{P_{t}}-C_{t}-P_{t}^{h} H_{t}-R_{t-1} \frac{B_{t-1}}{P_{t}}-w_{t}^{s} L_{t}^{S}-w_{t}^{b} L_{t}^{b}-I_{t}-\xi_{K t}\right. \\
& \left.\left.\left.-\xi_{H t}\right)\right]+\mu_{t}\left(m P_{t+1}^{h} H_{t} \pi_{t+1}-R_{t} \frac{B_{t}}{P_{t}}\right)+u_{t}\left(K_{t}-(1-\delta) K_{t-1}-I_{t}\right)\right\}
\end{aligned}
$$

شرايط مرتبه اول براى بنكاه كارآفرين نسبت به قيد بودجه و محدوديت قرض خيرى با وثايق

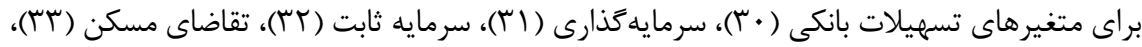

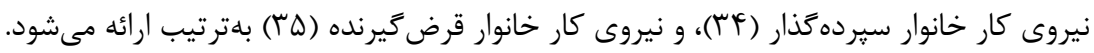


$\frac{B_{t}}{P_{t}}: \quad \frac{1}{C_{t}}=\gamma E_{t}\left\{\frac{R_{t}}{C_{t+1}}\left(\frac{P_{t}}{P_{t+1}}\right)\right\}+\mu_{t} R_{t}$

$I_{t}: \quad u_{t}=\frac{1}{C_{t}}\left(1+\frac{\psi_{K}}{\delta}\left(\frac{I_{t}}{K_{t-1}}-\delta\right)\right)$

$K_{t}: \quad u_{t}=\gamma \frac{1}{C_{t+1}}\left(\frac{\psi_{K}}{\delta}\left(\frac{I_{t+1}}{K_{t-1}}-\delta\right) \frac{I_{t+1}}{K_{t}}-\frac{\psi_{K}}{2 \delta}\left(\frac{I_{t+1}}{K_{t-1}}-\delta\right)^{2}\right)$

$$
+\gamma E_{t}\left(\frac{Y_{t+1}}{c_{t+1} X_{t+1} K_{t}}+u_{t+1}(1-\delta)\right)
$$

$H_{t}: \frac{P_{t}^{h}}{c_{t}}=E_{t}\left(\frac{\gamma}{c_{t+1}}\left(v \frac{Y_{t+1}}{X_{t+1} H_{t}}+\left(1-\delta_{H}\right) P_{t+1}^{h}\right)+\mu_{t} m \pi_{t+1} P_{t+1}^{h}\right)$

$L_{t}^{S}: \quad w_{t}^{S}=\frac{\alpha(1-\sigma-v) Y_{t}}{X_{t} L_{t}^{S}}$

$L_{t}^{b}: \quad w_{t}^{S}=\frac{(1-\alpha)(1-\sigma-v) Y_{t}}{X_{t} L_{t}^{b}}$

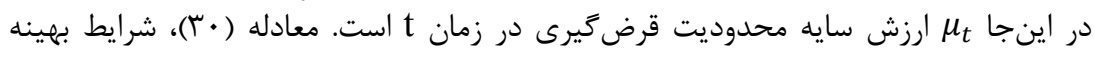

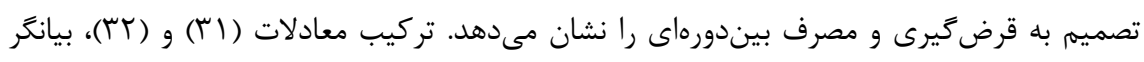

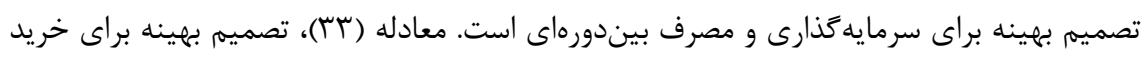

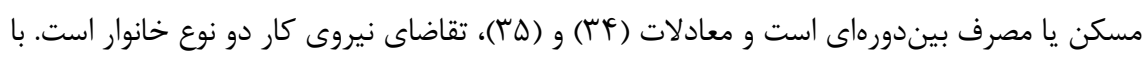

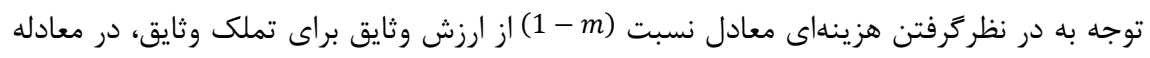

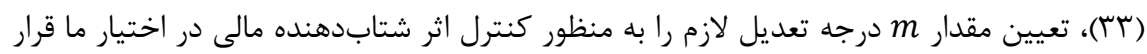

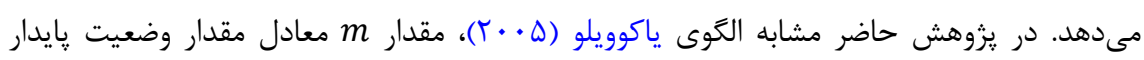
نسبت وام به ارزش اسمى وثايق و مطابق دستورالعمل هاى بانك مركزى كاليبره مى ئىود.

\section{توليدكنندهُ خردهروش}

تعداد زيادى از خردهفروشان در بازار رقابت انحصارى وجود دارند كه به يك نرمال مىشوند.

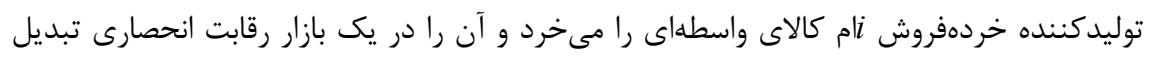

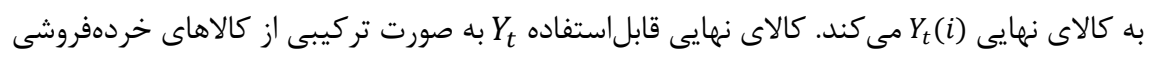
$Y_{t}=\left[\int_{0}^{1} Y_{t}(i)^{\frac{\epsilon-1}{\epsilon}} d i\right]^{\frac{\epsilon}{\epsilon-1}}$

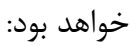


كه در آن $\epsilon$ كشش جانشينى ميان كالاهاى نهايى توليدشده است. با فرض قيمتكذارى (i) به عنوان قيمت اسمى كالاى iام، براى كمينه كردن هزينه خانوار شاخص قيمت

$P_{t}=\left[\int_{0}^{1} P_{t}(i)^{1-\epsilon} d i\right]^{\frac{1}{\epsilon-1}}$

خواهد بود: (TV)

با حل مسئله كمينهسازى تابع هزينه، تابع تقاضايى كه هر توليدكننده با آن مواجه است برابر

$Y_{t}(i)=\left[\frac{P_{t}(i)}{P_{t}}\right]^{-\epsilon} Y_{t}$

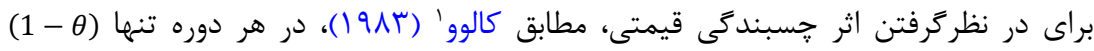

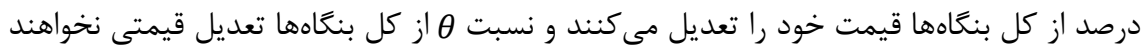

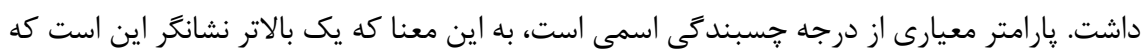

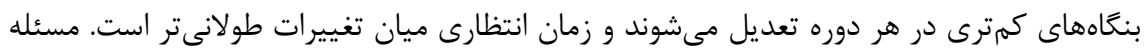

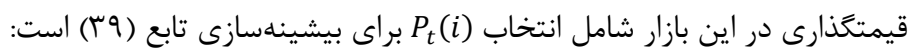
$\max _{P} E_{t}\left[\sum_{k=0}^{\infty} \theta^{k} \Delta_{t . t+k}\left(\left(\frac{P_{t}(i)}{P_{t+k}}\right) Y_{t+k}(i)-m c_{t+k}(i) Y_{t+k}(i)\right)\right]$

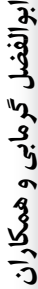
كه در آن براى بهدست آوردن $Y_{t+k}(i)$ $\max _{P^{*}} E_{t}\left[\sum_{k=0}^{\infty} \theta^{k} \Delta_{t . t+k}\left(\left(\frac{P_{t}^{*}(i)}{P_{t+k}}\right)^{1-\epsilon}-m c_{t+k}(i)\left(\frac{P_{t}^{*}(i)}{P_{t+k}}\right)^{-\epsilon}\right) Y_{t+k}\right]$ $P_{t}^{*}(i)=\frac{\epsilon}{1-\epsilon} \frac{E_{t}\left[\sum_{k=0}^{\infty} \theta^{k} \Delta_{t . t+k}\left(m c_{t+k}(i) Y_{t+k}(i)\right) / P_{t+k}\right]}{E_{t}\left[\sum_{k=0}^{\infty} \theta^{k} \Delta_{t . t+k}\left(Y_{t+k}(i)\right) / P_{t+k}\right]}$

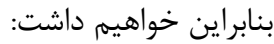
قيمت متوسط در دوره t عبارت است از:

$P_{t}=\left[\theta P_{t}^{1-\epsilon}+(1-\theta)\left(P_{t}^{*}\right)^{1-\epsilon}\right]^{\frac{1}{1-\epsilon}}$

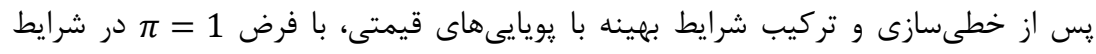

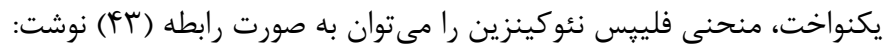
$\tilde{\pi}_{t}=\beta E_{t} \tilde{\pi}_{t+1}+\frac{(1-\theta)(1-\theta \beta)}{a} \widetilde{m c}_{t}+\varepsilon_{x}$ 


\section{بانك هاى تجارى}

در اين مدل بانكهاى تجارى به عنوان واسطه مالى با استفاده از تركيب سيردهها Do و سرمايه بانكى كارآفرين t سرمايه بانكها مرتبط مىشود. در اينجا بانكها با تابع هزينه تعديل سرمايه درجه دوم مواجه هستند و بهازاى اختلافى كه بين نسبت سرمايه به تسهيلات بانك $)$ نسئ نسبت ايجاد مىشود، مقدار هزينه تعديل سرمايه مزبور افزايش مى يابد. نسبت مزبور مىتواند به عنوان

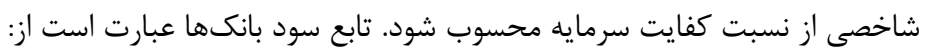
$\Pi_{t}=R\left(B_{t}^{b}+B_{t}\right)-R^{d} D_{t}-\frac{\phi}{2}\left(\frac{K_{t}^{b a}}{B_{t}^{b}+B_{t}}-v^{b}\right)^{2}\left(B_{t}^{b}+B_{t}\right)$

$\widetilde{K}_{t}^{b a}=\rho_{k} \widetilde{K}_{t-1}^{b a}+\varepsilon_{k . t}$

كه بانكها مى كوشند آن را با توجه به قيد ترازنامهاى خود بيشينه كنند: $B_{t}^{b}+B_{t}=D_{t}+K_{t}^{b a}$

از بهينهسازى تابع هدف بانكهاى تجارى نسبت به قيد ترازنامه رابطه نرخ بهره سيرده و نرخ

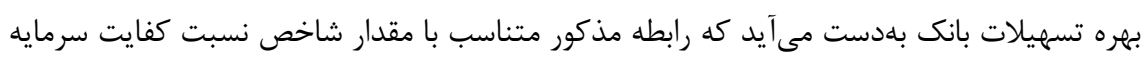
$R=R^{d}-\phi\left(\frac{K_{t}^{b a}}{B_{t}^{b}+B_{t}}\right)\left(\frac{K_{t}^{b a}}{B_{t}^{b}+B_{t}}-v^{b}\right)$ تغيير مى كند.

\section{سياستخَار :ولى}

بر اساس مباحثى كه در فصل ييشين ارائه شد و همجنين برخى از مطالعات مربوط به ادبيات سياست

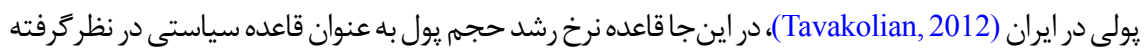

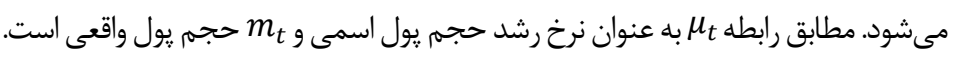
$\mu_{t}=\frac{m_{t}}{m_{t-1}} \pi_{t}$

در اين رابطه $\mu_{t}$ مى دهد. $\theta_{\text {و }} \theta_{y}$ بهترتيب رابط ضريب اهميتى است كه سياستخذار يولى براى شكاف تورم و توليد مي دهد. $\mu_{t}=\rho_{\mu} \mu_{t-1}+\theta_{\pi} \pi_{t}+\theta_{y} y_{t}+\varepsilon_{m o n}$ 
نقش دولت به عنوان سياستخذار مالى در مدل حاضر لحاظ شده است. قيد بودجه دولت به نحوى تعريف مى شود كه در آن مصارف شامل مخارج دولت مجموع درآمدهاى مالياتى $P_{t} g_{t}=T_{t}+O i l_{t}+\frac{M_{t}}{P_{t}}-\frac{M_{t-1}}{P_{t}}$ همجنين فرض مىشود كه در آمدهاى نفتى از فرايند (1) AR(1) مطابق الكوهاى زير ييروى مى كنند: Oil $_{t}=\rho_{O} O i l_{t-1}+\varepsilon_{O}$ در اينجا مالياتها شامل دو بخش ماليات بر ارزشافزوده و ماليات بر درآمد است كه به صورت رابطه (DT) تشريح مىشود:

$T_{t}=\tau_{c} C_{t}+\tau_{y} y_{t}$

\section{شرط تسويه بازار}

در بازار كالاهاى نهايى، شرط تعادل برابرى عرضه كل و تقاضا به صورت رابطه (rسه) است: $y_{t}+O i l_{t}=c_{t}^{s}+c_{t}^{b}+c_{t}+I_{t}+g_{t}$

در اين رابطه مجموع توليد كالاهاى نهايى غيرنفتى و نفتى با مجموع مصرف خانوار صبور، مصرف

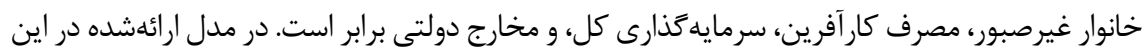
بخش، منشأ وجود اثر شتابدهنده مالى، وجود اصطكاك مالى ناشى از قيد وثيقه كيرى براى بنحاه كار آفرين و خانوار قرض تيرنده است. اين موضوع موجب جيرهبندى اعتبارات بر اساس قيمت وثايق ملكى خواهد شد. محدوديت قرض گيرى با استانداردها و معيارهاى حاكم بر اعطاى اعتبار بانكى كشور ايران كه مقدار

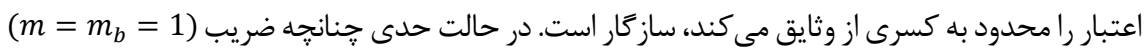

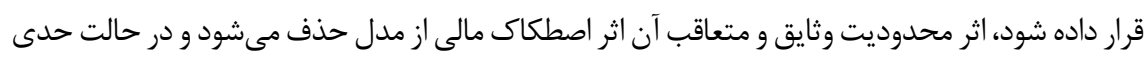
شاهد هستيم كه اثر اصطكاك مالى بيشينه مىشود. مدل حاضر اين امكان راد ادر اختيار

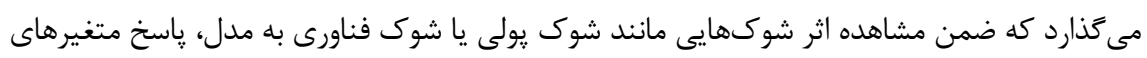

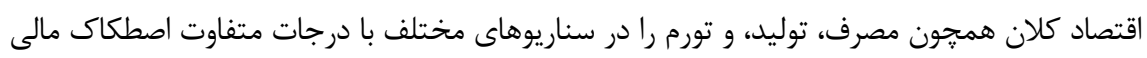

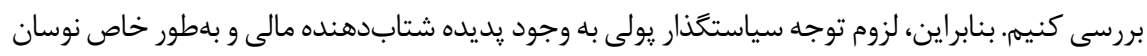




\section{نتايج بر آورد مدل}

در حل مدلهاى تعادل عمومى يوياى تصادفى پس از بهينهيابى رفتار فعالان اقتصادى با توجه

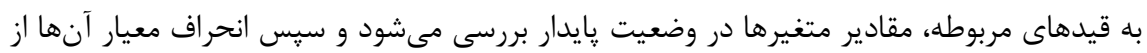
اين مسير در صورت وارد شدن شوكهاى مختلف به مدل ارزيابى مىشود. فرض اوليه در استخراج

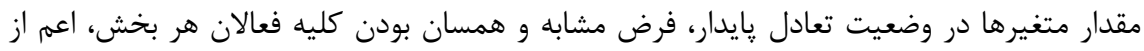

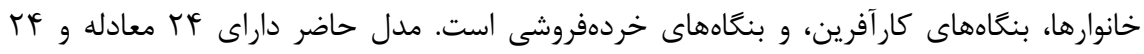
مجهول است كه يس از بهدست آوردن مقادير ماناى كليه متغيرها در سيستم معادلات معرفى شدهد

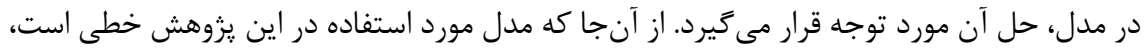

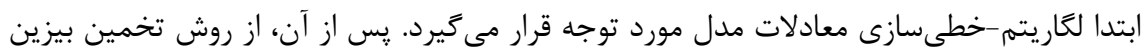

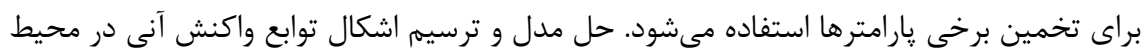
MATLAB و يارامترهاى مدل از مطالعات و مشاهدههاى يزوهش استفاده مىشود. در نهايت، يس از استفاده از

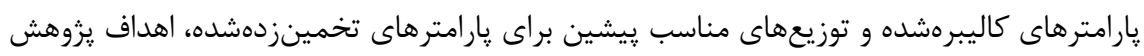

\section{كاليبراسيون و بر آورد الكوى مدل}

كاليبراسيون يكى از مهمترين مراحل ارزيابى تجربى مدلهاى تعادل عمومى يوياى تصادفى

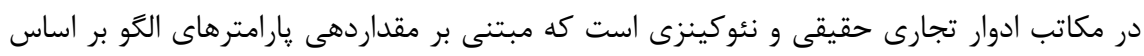

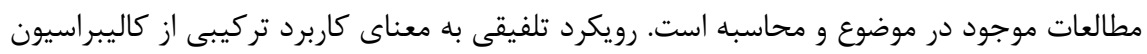

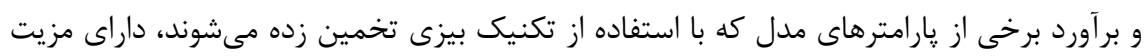

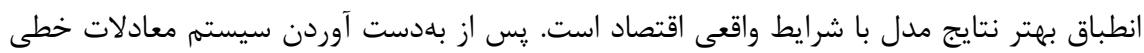
بخش قبل، در اين بخش كاليبراسيون مدل مد نظر قرار مى گيرد. با توجه به اين كه يزوهش حاضر در

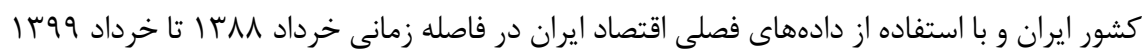

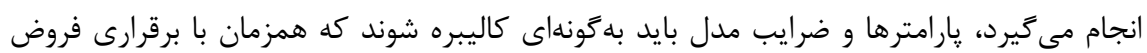
نظرى اقتصادى با روند متغيرهاى اقتصادى ايران همخوانى داشته باشند. بنابراين، براى كاليبراسيون يارامترها و ضرايب مدل علاوه بر مطالعات خارجى از برخى مطالعات ييشين در كشور ايران نيز 
استفاده مىشود. براى مثال، ارزيابىهايى متفاوتى از ضريب تنزيل براى كشور ايران وجود دارد مانند

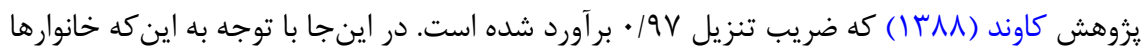
به دو دسته صبور و غيرصبور تقسيم شدهاند، فرض مىشود كه ضريب تنزيل اين دو دسته با فاصله

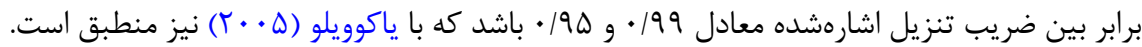
جدول (1)، به معرفى و مقداردهى يارامترهاى مدل به همراه منابع مورد استناد اختصاص دارد.

جدول ا: مقادير یارامترهاى مدل

\begin{tabular}{|c|c|c|c|c|c|c|c|}
\hline منبع & مقدار & تعريف & هار امتر & منبع & مقدار & تعريف & 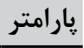 \\
\hline 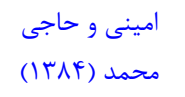 & $\cdot / \cdot$ tr & نرخ استهلاك & $\delta$ & 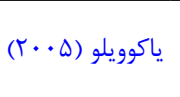 &.$/ 99$ & مطلوبيت خانوار سيرده كذار & $\beta$ \\
\hline محاسبههاى مدل & $.11 \cdot 9$ & دولت به هزيته درآمد نفتى & $O / G$ & ياكوويلو (ه • ‘) & $\cdot / 90$ & عامل تنزيل در تابع & $\beta_{b}$ \\
\hline محاسبههاى مدل & $\cdot / 4$ & نسبت ماليات به هزينه & $T / G$ & ياكوويلو (ه • r) & $\cdot / 91$ & مطلوبيت كار آفرين در تابع & $\gamma$ \\
\hline محاسبههاى مدل & $\cdot / 1 \mathrm{~V}$ & نوبت هزينه دولت به & $G / Y$ & 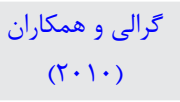 & $\cdot / r$ & مطلوبيت خانوار در تابع & $\vartheta^{h}$ \\
\hline محاسبههاى مدل & $\cdot 1 \cdot 11$ & نسبت درآمد نفتى به & $0 / Y$ & محاسبه ماى & .1 .9 & نرخ ماليات بر مصرف & $\tau_{c}$ \\
\hline 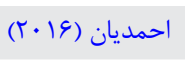 & N/9 & يارامتر تعديل سرمايه & $\psi_{K}$ & محاسبههاى مدل &.$/ 10$ & نرخ ماليات بر درآمد & $\tau_{y}$ \\
\hline ياكوويلو (r.a) & . & $\begin{array}{l}\text { سهم مسكن و ساختمان } \\
\text { در تابع توليد }\end{array}$ & $v$ & 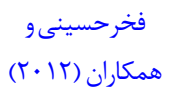 & $1 / T V q$ & نرخ ماركى & $\mathrm{X}$ \\
\hline طايى (V. • (T) & $T / I V$ & عار نسبت كشش عرضه دستمزوى & $\eta$ & محاسبه هاى & G1.r & نسبت نقدينكى به هزينه & $M / G$ \\
\hline و اجراى وثايق & $\cdot / r V$ & 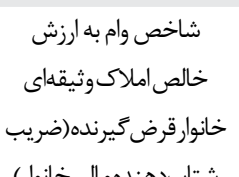 & $m^{b}$ & ونايقو تضمينها وماجراى & $\cdot / \pi \Delta$ & شاخص وام به ارزش خالص & $m$ \\
\hline محاسبه هاى مدل & & شتابدهندهمالى خانوار) & & مدل & & كارأفرين) & \\
\hline محاسبههاى مدل & . $/$ TS & تسبهيتات سرمايه به بانكها & $\frac{K^{b a}}{B^{b}+B}$ & ستورالعملنسبت & $\cdot 1 \cdot 1$ & نسبت بهينه سرمايه به & $v^{b}$ \\
\hline
\end{tabular}


براى برآورد ساير پارامترهاى الكو از روش بيزى و الكوريتم مترويوليس ـ هستينكز' استفاده

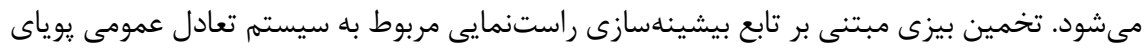

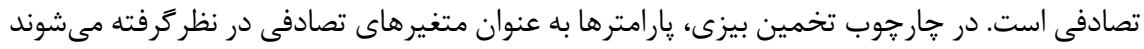

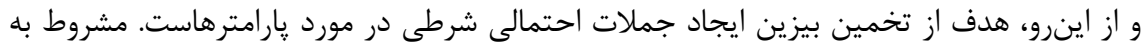

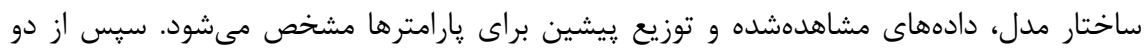

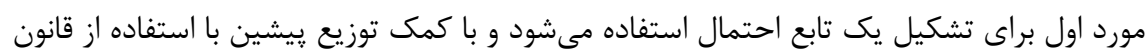

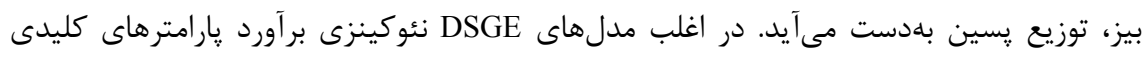

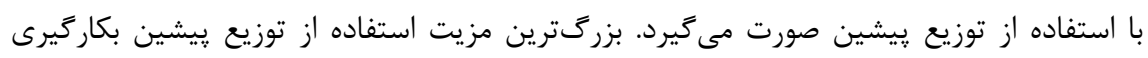

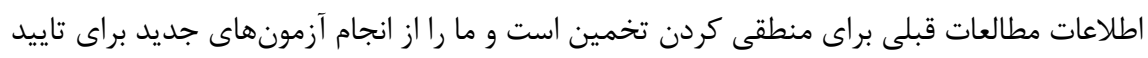

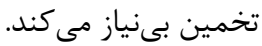

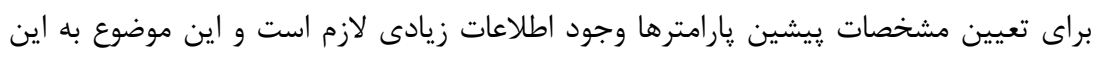

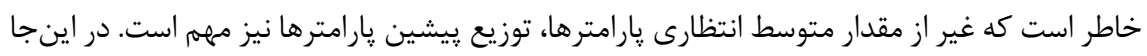

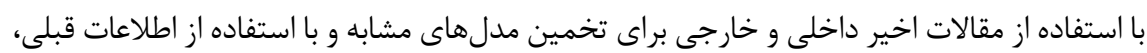

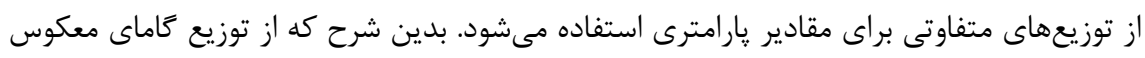

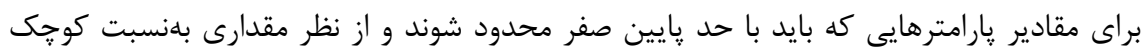

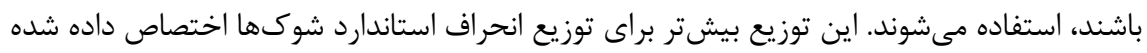

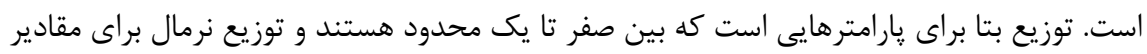

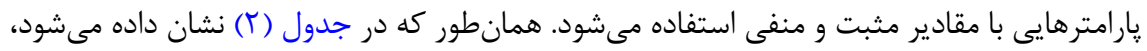

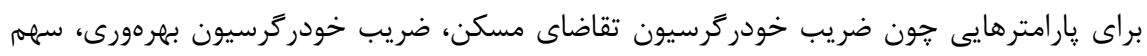

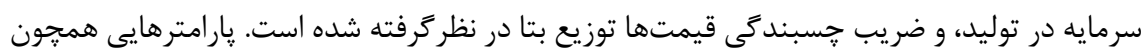

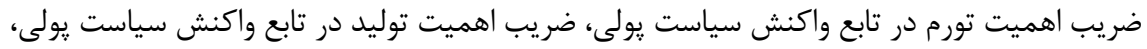

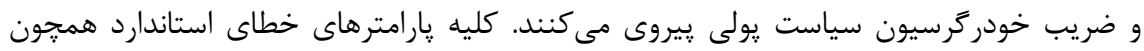

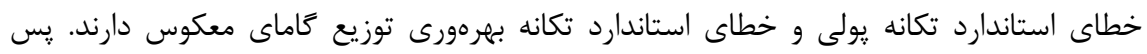

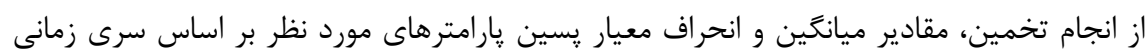

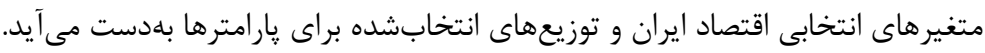


جدول r: نتايج بر آورد يّارامترهاى مدل

\begin{tabular}{|c|c|c|c|c|c|c|c|c|}
\hline \multicolumn{2}{|c|}{ توزيع هيسين } & \multirow{2}{*}{\multicolumn{2}{|c|}{ فاصله اطمينان }} & \multicolumn{2}{|c|}{ توزيع يِيشين } & \multirow[b]{2}{*}{ توزيع } & \multirow[b]{2}{*}{ 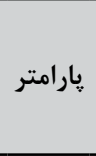 } & \\
\hline انحراف & ميانغين & & & انحراف & ميانغين & & & \\
\hline.$/ 1$ & $\cdot / 4 \cdot 91$ & $\cdot|\Delta \& 9|$ & $\cdot / r \wedge \Delta$ &.$/ 1$ & . IAT & بتا & $\rho_{\vartheta}$ & ضريب خودرگرسيون \\
\hline .11 &.$/ 9 V F V$ & •/994 & $\cdot / 9 \Delta \vee \Delta$ &.$/ 1$ & $\cdot / V V$ & بتا & $\rho_{a}$ & ضريب خودركرسيون \\
\hline$\cdot 1 \cdot \Delta$ & ./TG人 & & - IIVFA & $\cdot 1 \cdot \Delta$ & $\cdot / r \Lambda$ & بتا & $\sigma$ & سهم سرمايه در توليد \\
\hline$\cdot 1 \cdot \Delta$ &. $\mid G Y \wedge \Delta$ & .19919 & $\cdot|\Delta \varepsilon| \Lambda$ & $\cdot / \cdot \Delta$ & $.18 T$ & بتا & $\alpha$ & خريب سهمم نيروى كار \\
\hline.$/ 1$ & $\cdot|V| \cdot \Delta$ & - IAAVT &.$/ \Delta q 4 V$ & $\cdot 11$ & $\cdot|V|$ & بتا & $\theta$ & احتمال ثابت ماندن قيمتها \\
\hline$\cdot / T \Delta$ & $-1 / 9 \cdot \wedge V$ & - I/GHF & D/TID & $\cdot / T \Delta$ & $-T / \mathcal{F}$ & 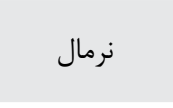 & $\theta_{\pi}$ & ضريب اهميت تورم در تابع \\
\hline$\cdot / T \Delta$ & -.199114 &.$- / A T F$ & $-\cdot|\Lambda \Delta|$ & $\cdot / T \Delta$ & $-1 / 1$ & 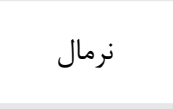 & $\theta_{y}$ & ضريب اهميت توليد در تابع \\
\hline$\cdot 1 \cdot \Delta$ & .19197 & - IDFTE & . GAVK & $\cdot 1 \cdot \Delta$ & $\cdot|N|$ & 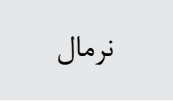 & $\rho_{\mu}$ & ضريب خودر رَسيون \\
\hline$\cdot 1 \cdot \Delta$ & $\cdot / 19 \cdot V$ & Tr & . /11rA & $\cdot / \cdot \Delta$ & $\cdot / \cdot 1$ & كاماى معكوس & $\varepsilon_{m o n}$ & خطاى استاندارد تكانه يولى \\
\hline$\cdot 1 \cdot \Delta$ & . IATVK & $1 / .914$ & - IVTAV & $\cdot / \cdot \Delta$ &.$/ \cdot 1$ & كاماى معكوس & $\varepsilon_{x}$ & $\begin{array}{c}\text { خطاى استاندارد تكانه } \\
\text { Cost Push }\end{array}$ \\
\hline$\cdot / \cdot \Delta$ & $9 / 49$ & V/ArV & $F / \Delta V I S$ & $\cdot / \cdot \Delta$ & $.1 \cdot 1$ & كاماى معكوس & $\varepsilon_{\vartheta}$ & خطاى استاندارد تكانه \\
\hline$\cdot 1 \cdot \Delta$ & $.1 .9 \mathrm{Vr}$ & $\cdot / \cdot \Lambda \Lambda$ & . . pet & $\cdot 1 \cdot \Delta$ & $\cdot / \cdot 1$ & كاماى معكوس & $\varepsilon_{A}$ & خطاى استاندارد تكانه \\
\hline
\end{tabular}

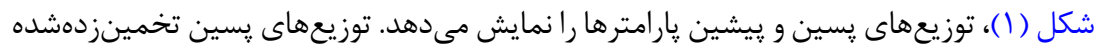

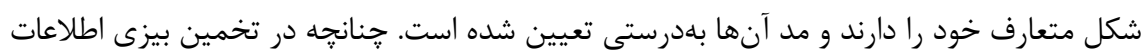

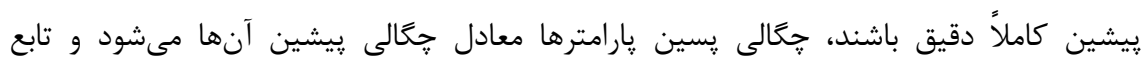
درستنمايى اطلاعاتى بيش از اطلاعات موجود ندارد. در غير اين صورت، روش تخمين بيزى تبديل 
به برآورد بيشينهُ درستنمايى مىشود. در حالت بينابينى، رويكرد بيزى روشى بين كاليبراسيون

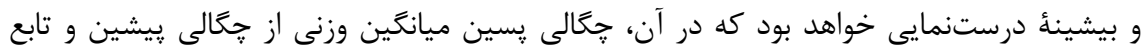

درستنمايى است (Hamilton, 1994).
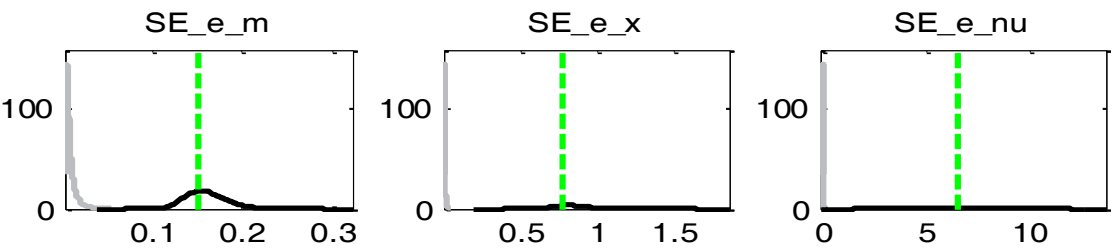

SE_e_a
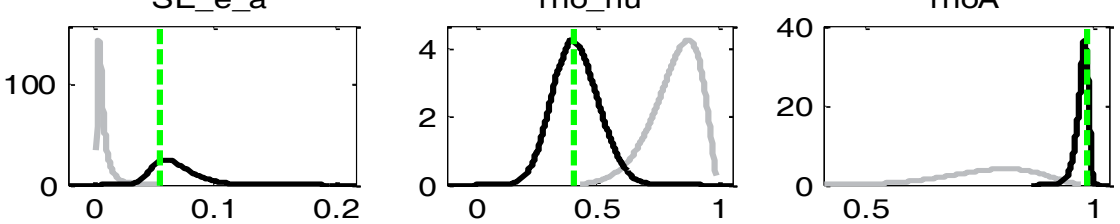

alfa
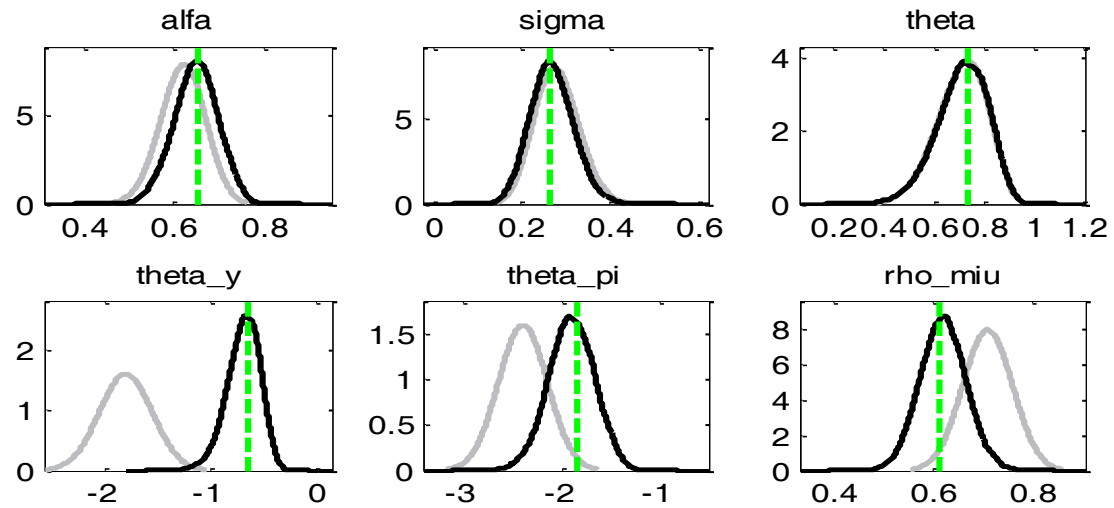

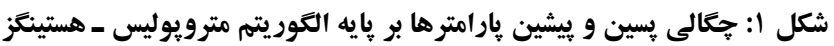

\section{نتايج رفتار توابع واكنش آنى}

در اين بخش، نحوه رفتار توابع واكنش آنى متغيرهاى مدل در برابر شوكهاى ثولى، فناورى، ترجيحات مسكن، و شوك در آمد نفتى مورد بررسى قرار مى گيرد. همجنين، مقايسه توابع واكنش آنى مئى 
در دو سناريوى بيشينه بودن درجه اصطكاك مالى و درجات يايينتر اصطكاك مالى (سناريوى پايه)

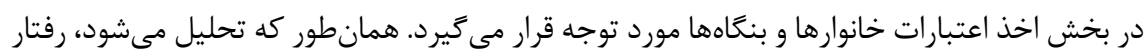

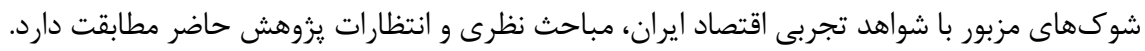

\section{شوى يولى}

همانطور كه انتظار مىرود، يك تكانه مثبت يولى سبب افزايش تورم و توليد مىشود. اخرجه

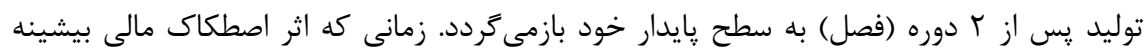
است (m=LTV=0) أثر شوى اوليه بر توليد بهطور ملموسى كمتر است و از سوى ديكر، اثر آن زودتر خنثى مىشود. با در نظركرفتن بيشينهُ اصطكاك مالى، قيمت مسكن در

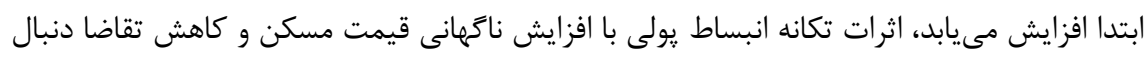

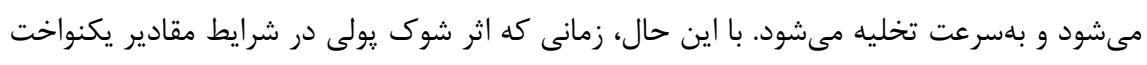

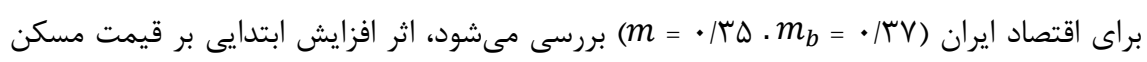

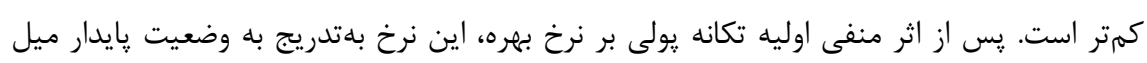

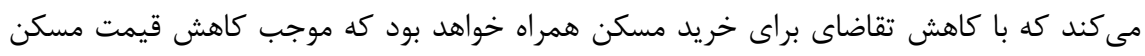

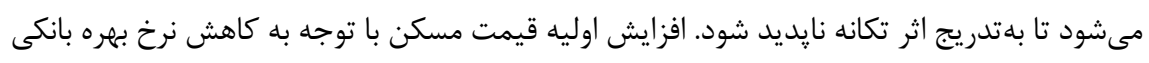

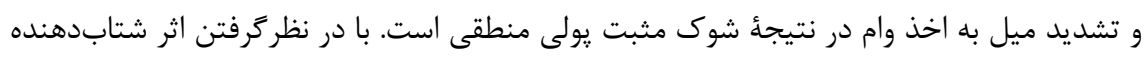

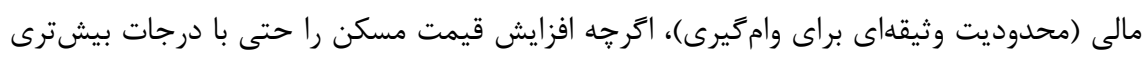
شاهد هستيم، ولى افزايش اوليه قيمت مسكن به دليل پايدارى تقاضاى مسكن و و تداوم وثيقه كذارى

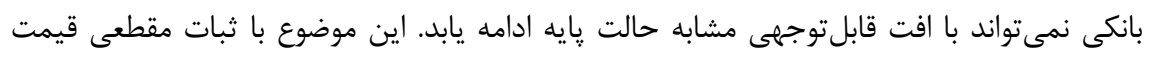

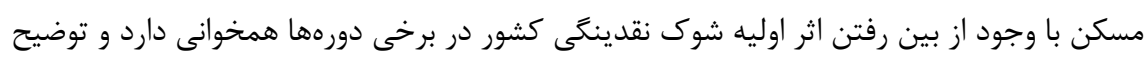

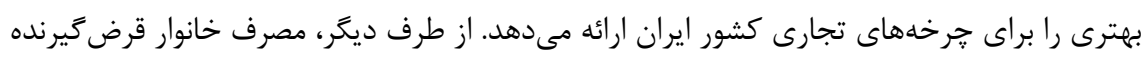

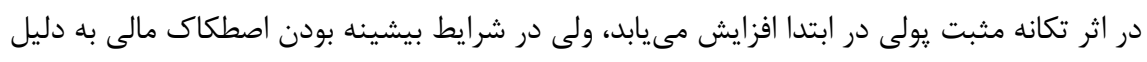

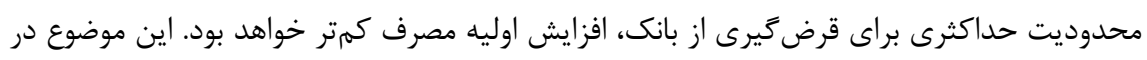

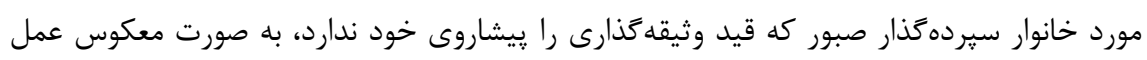
مى كند. سرمايه گذارى و هزينههاى دولت در هر دو حالت با افزايش اوليه همراه هستند، ولى با بيشينه

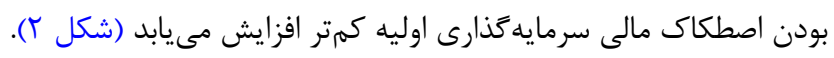



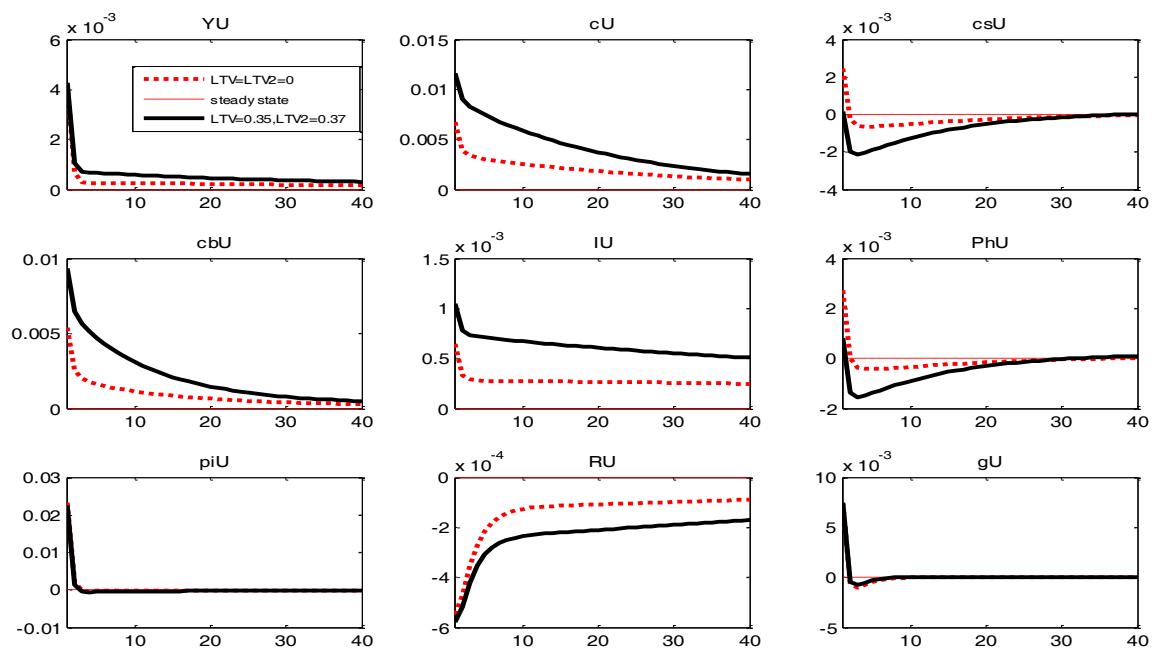

شكل r: توابع واكنش آنى متغيرها به تكانه يولى

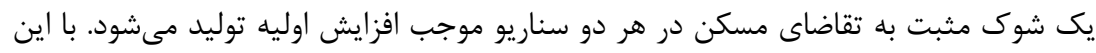

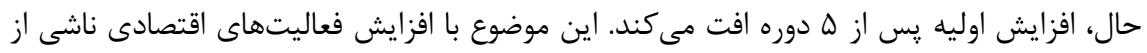

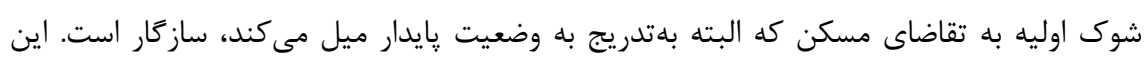

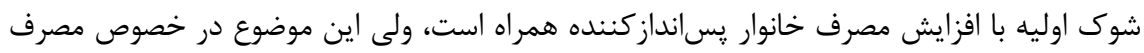

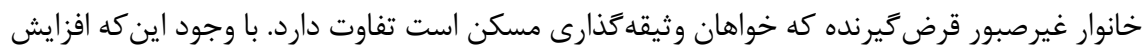

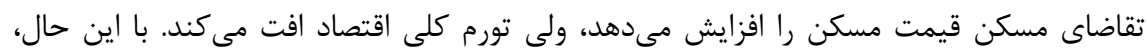

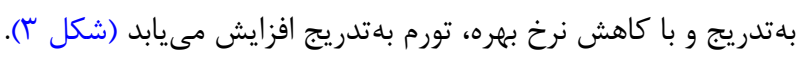



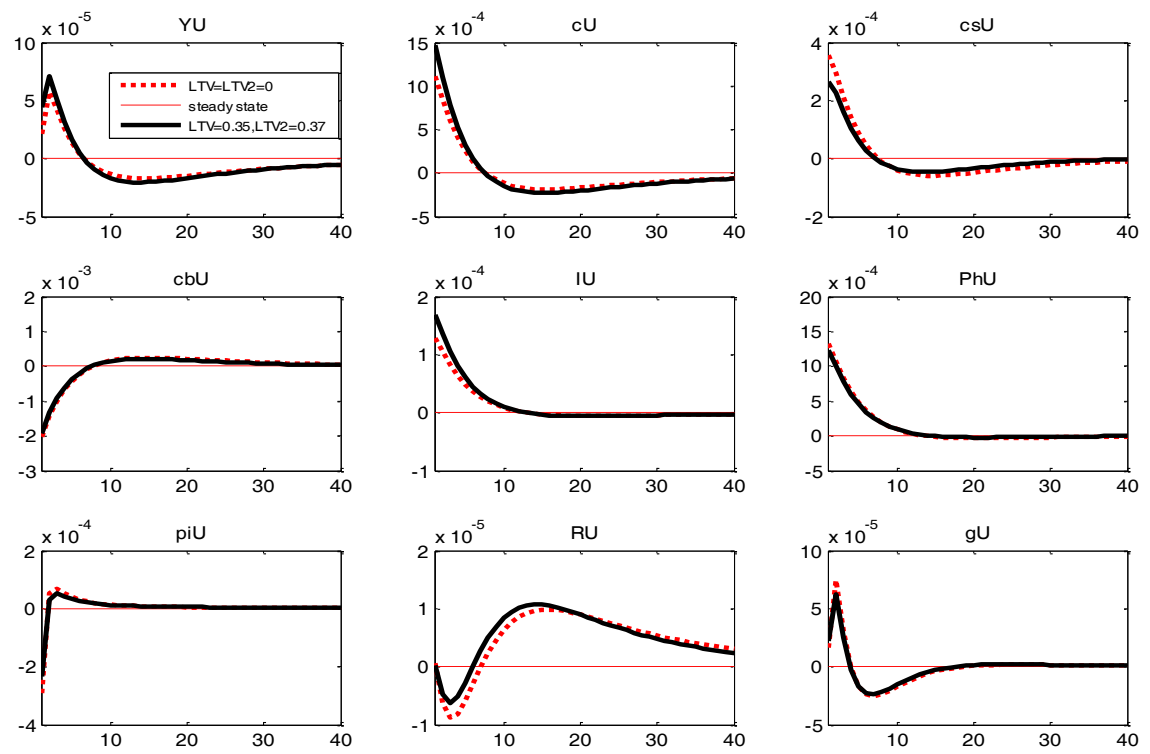

شكل r: توابع واكنش آنى متغيرها به تكانه ترجيحات مسكن

يكى شوك بهرهورى مثبت به اقتصاد اثرات واقعى دارد. همانطور كه شكل (أ) در مورد توليد

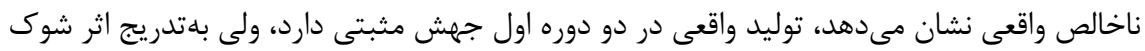
اوليه از بين مىرود و يس از · ل دوره توليد به وضعيت پايدار برمى گردد. كشش بسيار پايين حجم

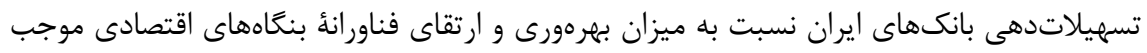

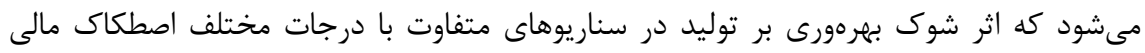

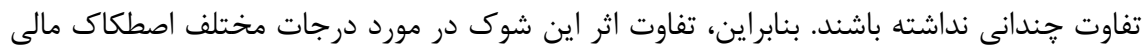

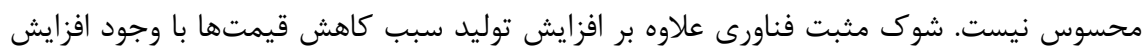

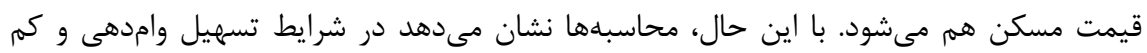

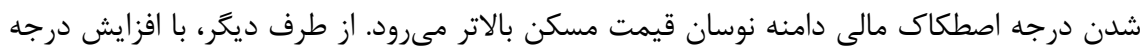
اصطكاى مالى و اثرگذارى بيشتر ارزش خالص بنگاه در مقدار تسهيلات قابلدريافت از بخش بانكى، 
شوك فناورى اثركذارى اوليه بالاترى بر ميزان اخذ وام بنعاه كارآفرين و افزايش سرمايهَذارى خواهد

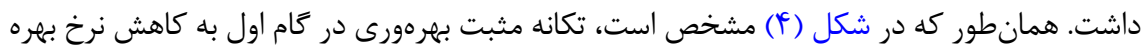
مى انجامد. كاهش اوليه نرخ بهره حقيقى با كاهش نرخ تورم همراه مىشود. در هر دو سناريو، شوك

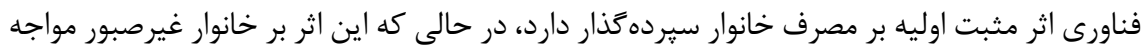

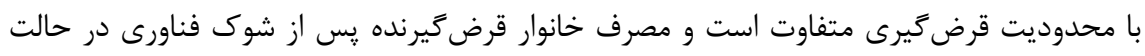
بيشينه بودن اصطكاك مالى، با افزايش اوليه بيشترى مواجه است.
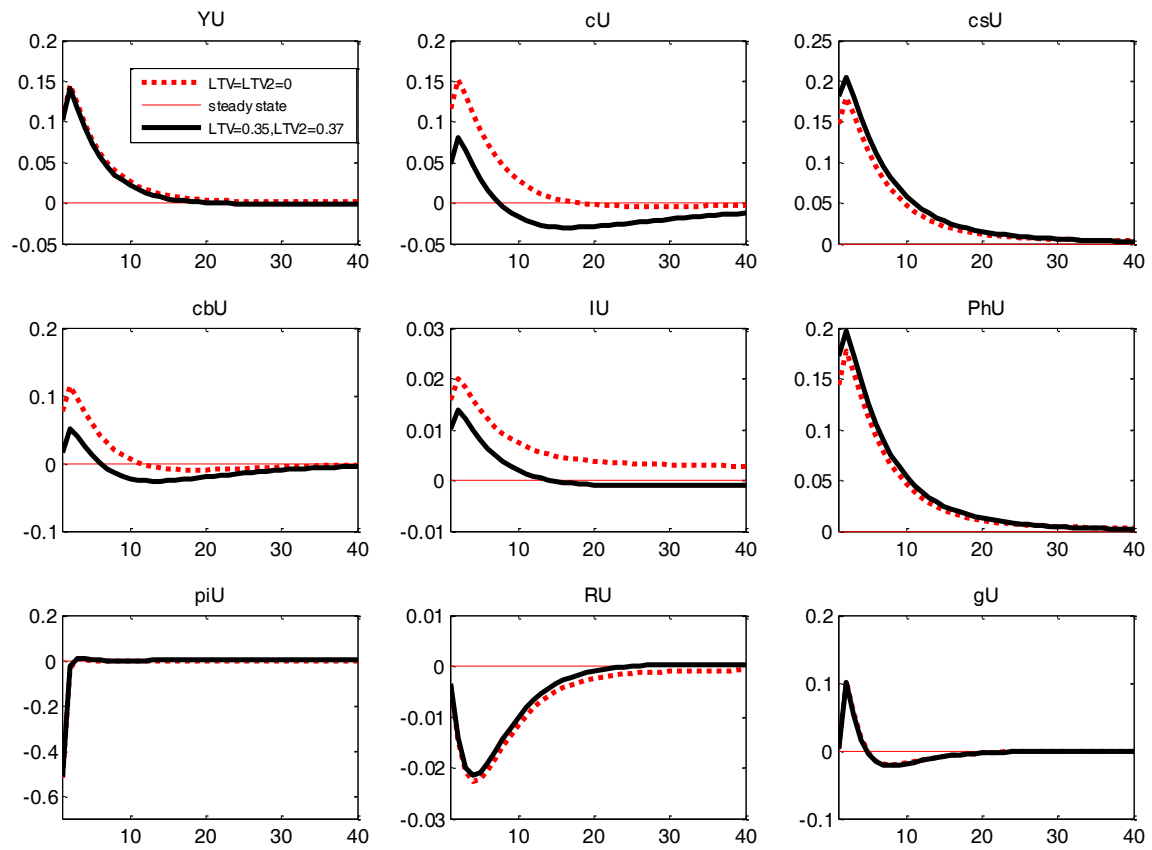

شكل †: توابع واكنث آنى متغيرها به تكانه فناورى

در صورت بروز شوك مثبت درآمد نفتى، مخارج دولت با افزايش اوليه مواجه مىشود. پِ از افزايش محسوس مخارج دولت توليد نيز به ميزان قابلتوجهى زياد مىشود. به دنبال افزايش نقدينكى 
كه به دنبال شوك نفتى رخ مى دهد، تورم متناسب با آن افزايش مىيابد. در اين ميان، با وجود اين كه

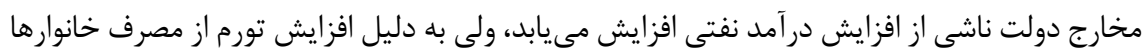
در هر دو سناريو كاسته مىشود. ولى اين كاهش اوليه مصرف به دليل تعديل نرخ تورم و انتقال نقدينكى جديد ناشى از رشد يايه يولى يس از له دوره به افزايش مصرف خانوارها بهويزه خانوارهاى

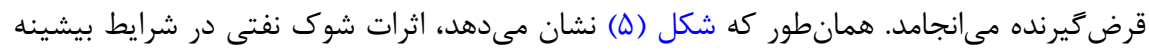
بودن درجه اصطكاك مالى بر متغير توليد بالاتر است.
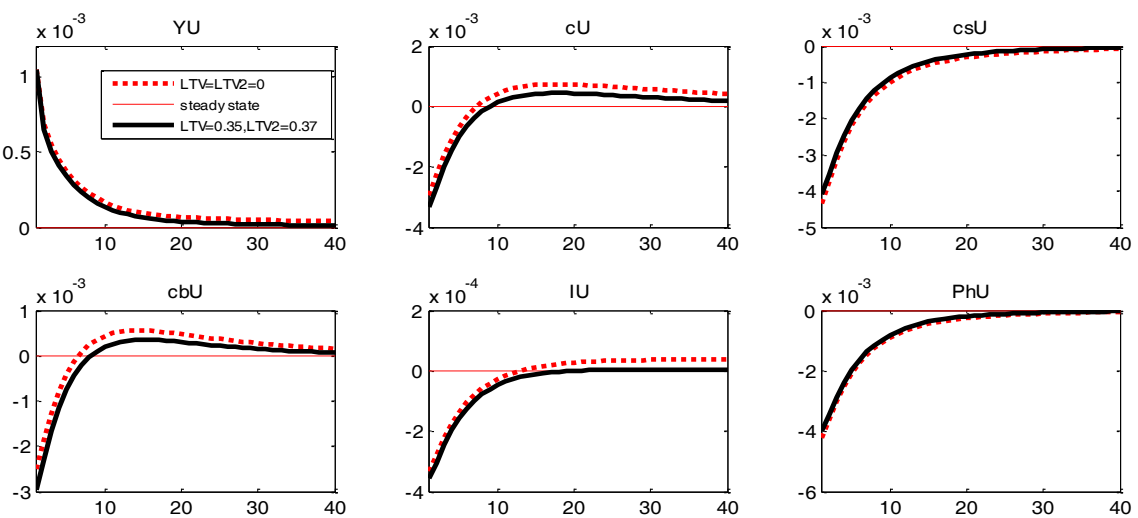

112
3
3
5
3
3
-5
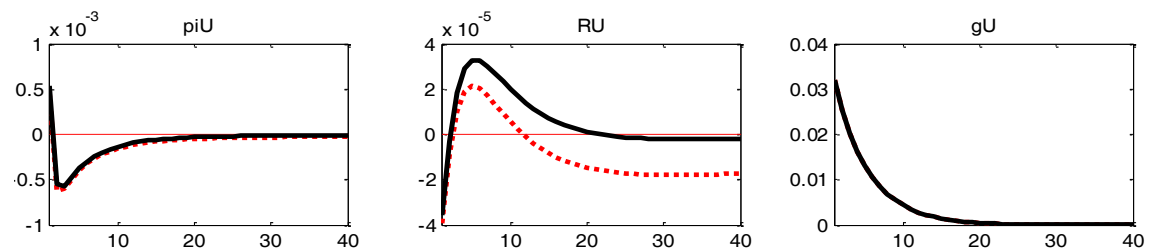

شكل ه: توابع واكنث آنى متغيرها به تكانه نفتى

\section{بحث و نتيجه}

اين يزوهش به بررسى نقش شتابدهنده ناشى از اصطكاك مالى در ادوار تجارى اقتصاد ايران

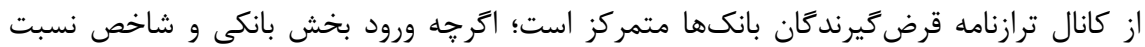
كفايت سرمايه آنها به مدل يزوهش نقش ترازنامه بانكها را در بروز اصطكاك مالى اقتصاد ايران 
نيز وارد مدل مى كند. با توجه به ضعف مولفه اعتبارسنجى مشتريان بانكى در كشور ايران، در اغلب

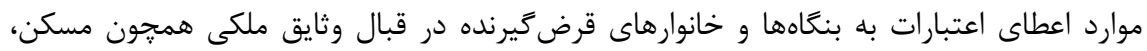
ساختمان، و زمين و بدون تحميل نرخهاى بهره متنوع به تسهيلات گيرندًان انجام مىشود. بنابراين، براى درى صحيح يديده اصطكاك مالى در نظام اعتبارى كشور ايران و بررسى اثر شتابدهنده مالى بـى برهي

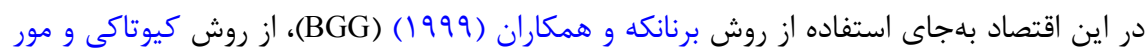

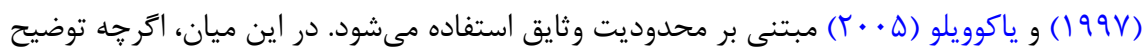
اثر شتابدهنده مالى در شرايط تورمى اقتصاد ايران مطابق با الكوى ياكوويلو (ه • +؟) قابلتوضيح

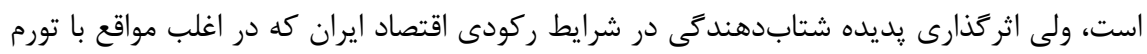

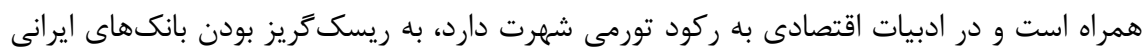
در مواجهه با مشتريانى كه در قبال وثايق يرارزش درخواست تسهيلات دارند، برمى بانكداران از نقد نشدن وثيقهاى مزبور در شرايط ركود تورمى موجب كاهش اعطاى تسهيلات و وايين

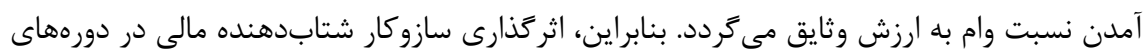
ركود تورمى همجون ساير دورههاى ركودى تاييد مى شود. تخمينهاى يزوهش حاضر با استفاده از رويكرد بيزين و دادههاى روندزدايىشده اقتصاد ايران

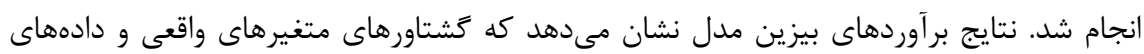

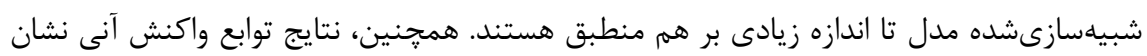
مى دهد كه در شرايط فرض بيشينه بودن درجه اصطكاك مالى كه در كاليبراسيون يارامتر نسبت وام به ارزش وثايق ظاهر مىشود و در مدل با (LTV

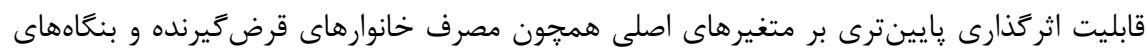

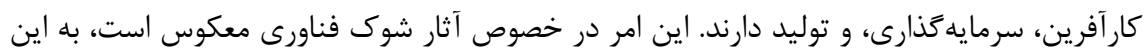
معنا كه با افزايش درجه اصطكاك مالى نسبت به سناريوى پايه، قابليت اثركذارى شوك فناورى بر

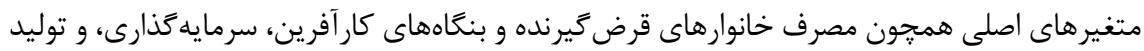

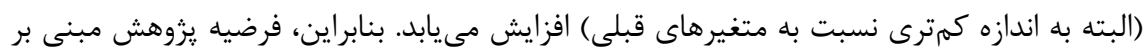

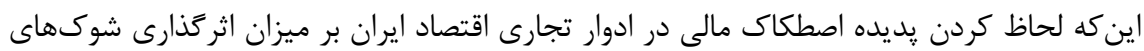
يولى و حقيقى و در نتيجه توابع واكنش آنى متغيرهاى اصلى مدل موثر است، تاييد مى شود؛ اتر جه

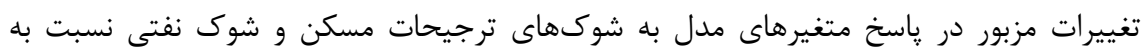


الكَى طراحىشده در اين يزوهش به سياستخذار اقتصادى كمك مى كند كه در مواجهه با

تكانههاى مختلف، با در نظركرفتن اثر شتابدهنده مالى، درك بهترى از آثار اين تكانهها داشته

باشد و با اعمال سياستهاى مناسب، ناكارايىهاى محتمل بهويزه در حوزه اعطاى تسهيلات بانكى

را كمينه نمايد. توجه به شاخصهاى سلامت بانكى بلويزه نسبت كفايت سرمايه از سوى سياستخذار

نيز مى تواند با كاستن از درجه اصطكاك مالى به تحقق اهداف يولى كمك شايانى نمايد. يِيشنهاد

مىشود در يزوهشهاى آتى الكوى حاضر با تصريح بازار بينبانكى و سياستخذارى بانك مركزى در اين خصوص بسط يابد.

Ahmadyan, A. (2016). Modeling a Dynamic Stochastic General Equilibrium Model for the Iranian Bank Withdrawal. The Journal of Economic Policy, 7(14), 77-103. http://ep.yazd.ac.ir/article_717.html

Altman, E. I., \& Saunders, A. (2001). An Analysis and Critique of the BIS Proposal on Capital Adequacy and Ratings. In Risk Management: The State of the Art (pp. 167-186): Springer.

Arslan, Y., Guler, B., \& Kuruscu, B. (2020). Credit Supply Driven Boom-Bust Cycles. BIS Working Papers No. 885. http://dx.doi.org/10.2139/ssrn.3573994

Bartmann, R. (2017). Causes and Effects of 2008 Financial Crisis: Hochschule Furtwangen.

Bernanke, B. S., Gertler, M., \& Gilchrist, S. (1999). The Financial Accelerator in a Quantitative Business Cycle Framework. Handbook of Macroeconomics, 1(1), 13411393. https://doi.org/10.1016/S1574-0048(99)10034-X

Beutler, T., Bichsel, R., Bruhin, A., \& Danton, J. (2020). The Impact of Interest Rate Risk on Bank Lending. Journal of Banking \& Finance, 115(1), 105797. https://doi.org/10.1016/j.jbankfin.2020.105797

Blanchard, O. J., \& Kahn, C. M. (1980). The Solution of Linear Difference Models under Rational Expectations. Econometrica: Journal of the Econometric Society, 48(5), 13051311. https://doi.org/10.2307/1912186

Borio, C., Furfine, C., \& Lowe, P. (2001). Procyclicality of the Financial System and Financial Stability: Issues and Policy Options. BIS Papers, 1(3), 1-57. http://dx.doi.org/10.2139/ssrn.1165494

Calvo, G. A. (1983). Staggered Prices in a Utility-Maximizing Framework. Journal of Monetary Economics, 12(3), 383-398. https://doi.org/10.1016/0304-3932(83)90060-0

Carlstrom, C. T., \& Fuerst, T. S. (1997). Agency Costs, Net Worth, and Business Fluctuations: A Computable General Equilibrium Analysis. The American Economic Review, 87(5), 893-910.

Dargahi, H., \& Hadian, M. (2016). Evaluation of Fiscal and Monetary Shocks with 
Emphasis on the Interactions of Banking System Balance Sheet and the Real Sector of Iran's Economy: A DSGE Approach. Quarterly Journal of Applied Theories of Economics, 3(1), 1-28. https://ecoj.tabrizu.ac.ir/article_4828.html

Dib, A. (2010). Banks, Credit Market Frictions, and Business Cycles. Bank of Canada Working Paper No. 24.

Fakhrehosseini, S. F., Shahmoradi, A., \& Ehsani, M. A. (2012). Sticky Prices, Wages and Monetary Policy in the Iranian Economy. The Economic Research, 12(1), 1-30. http://ecor.modares.ac.ir/article-18-6736-fa.html

Farzin Vash, A., Ehsani, M. A., \& Keshavarz, H. (2015). Financial Frictions and Labor Market Fluctuations (Case Study Iran's Economy as a Small Open Economy). Journal of Economic Research (Tahghighat-E-Eghtesadi), 50(2), 415-447. https://dx.doi.org/10.22059/jte.2015.55088

Gerali, A., Neri, S., Sessa, L., \& Signoretti, F. M. (2010). Credit and Banking in a DSGE Model of the Euro Area. Journal of Money, Credit and Banking, 42(1), 107-141. https://doi.org/10.1111/j.1538-4616.2010.00331.x

Gertler, M. (1988). Financial Structure and Aggregate Economic Activity: An Overview. Journal of Money, Credit and Banking, 20(3), 559-588. https://doi.org/10.2307/1992535

Gertler, M., \& Bernanke, B. (1989). Agency Costs, Net Worth and Business Fluctuations. In Business Cycle Theory: Edward Elgar Publishing Ltd.

Goodhart, C., Hofmann, B., \& Segoviano, M. (2004). Bank Regulation and Macroeconomic Fluctuations. Oxford Review of Economic Policy, 20(4), 591-615. https://doi.org/10.1093/oxrep/grh034

Hamilton, J. (1994). Time Series Econometrics: Princeton University Press Princeton.

Holmstrom, B., \& Tirole, J. (1997). Financial Intermediation, Loanable Funds, and the Real Sector. The Quarterly Journal of Economics, 112(3), 663-691. https://doi.org/10.1162/003355397555316

Iacoviello, M. (2005). House Prices, Borrowing Constraints, and Monetary Policy in the Business Cycle. American Economic Review, 95(3), 739-764.

Iacoviello, M., \& Neri, S. (2010). Housing Market Spillovers: Evidence from an Estimated DSGE Model. American Economic Journal: Macroeconomics, 2(2), 125-164.

Jacques, K. T. (2008). Capital Shocks, Bank Asset Allocation, and the Revised Basel Accord. Review of Financial Economics, 17(2), 79-91. https://doi.org/10.1016/j.rfe.2007.03.003

Kiyotaki, N., \& Moore, J. (1997). Credit Cycles. Journal of Political Economy, 105(2), 211-248.

Lowe, P. W. (2002). Credit Risk Measurement and Procyclicality. BIS Working Paper No. 116. http://dx.doi.org/10.2139/ssrn.846268

Modigliani, F., \& Miller, M. H. (1958). The Cost of Capital, Corporation Finance and the Theory of Investment. The American Economic Review, 48(3), 261-297.

Pietrunti, M. (2017). Financial Frictions and the Real Economy. ESRB Working Paper Series No. 41

Shahhoseini, S., \& Bahrami, J. (2016). Assessment of Macroeconomic Fluctuations and Monetary Transmission Channel in Iran; Dynamic Stochastic General Equilibrium Approach. Journal of Economics Research, 16(60), 1-49. https://dx.doi.org/10.22054/joer.2016.4200

Suh, H. (2012). Macroprudential Policy: Its Effects and Relationship to Monetary Policy. 
FRB of Philadelphia Working Paper No. 12-28. http://dx.doi.org/10.2139/ssrn.2182741 Taei, H. (2007). An Estimation of Labour Supply Function Using the Iranian Micro Data. Iranian Journal of Economic Research, 8(29), 93-112. http://ijer.atu.ac.ir/article_3675.html

Tavakolian, H. (2012). A New Keynesian Phillips Curve in a DSGE Model for Iran. Journal of Economic Research (Tahghighat-E-Eghtesadi), 47(3), 1-22. https://dx.doi.org/10.22059/jte.2012.29251

Townsend, R. M. (1979). Optimal Contracts and Competitive Markets with Costly State Verification. Journal of Economic Theory, 21(2), 265-293. https://doi.org/10.1016/0022-0531(79)90031-0

Van den Heuvel, S. (2002). Does Bank Capital Matter for Monetary Transmission? Economic Policy Review, 8(1), 259-265.

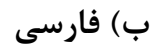

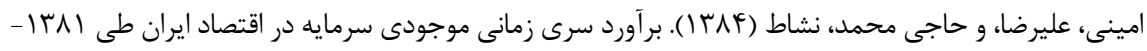

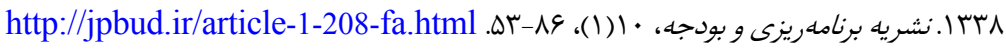

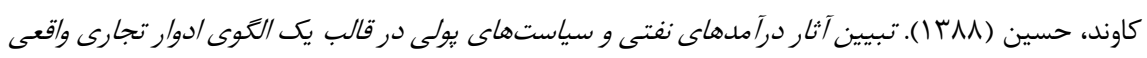

$$
\begin{aligned}
& \text { براى /قتصاد/يران. پايان نامه دكترى، دانشكده اقتصاد، دانشكاه تهران. }
\end{aligned}
$$

